\title{
Mineralogy and chemical composition of ferromanganese crusts from the Cruzeiro do Sul Lineament - Rio Grande Rise, South Atlantic
}

\author{
Sousa I.M.C. ${ }^{1,}{ }^{*}$, Santos R.V. ${ }^{1}$, Koschinsky A. ${ }^{2}$, Bau M. ${ }^{2}$, Wegorzewski A.V. ${ }^{3}$, Cavalcanti J.A.D. ${ }^{4}$, \\ Dantas E.L. 1
}

1 Instituto de Geociências, Universidade de Brasília, Campus Universitário Darcy Ribeiro, 70910-900, Brasília - DF, Brazil

2 Department of Physics and Earth Sciences, Jacobs University Bremen, Campus Ring 1, 28759,

Bremen, Germany

3 BGR , Bundesanstalt für Geowissenschaften und Rohstoffe, Stilleweg 2, 30655, Hannover, Germany

${ }^{4}$ CPRM , Geological Survey of Brazil, Av. Brasil 1731, 30140-002, Belo Horizonte, MG, Brazil

*Corresponding author : I.M.C. Sousa, email address : isabela.sousa@unb.br

\begin{abstract}
:
Samples dredged from the Cruzeiro do Sul Lineament exhibit ferromanganese crusts precipitated above phosphate-rich substrates (phosphorites, phosphate-impregnated volcanic rocks and older phosphatized ferromanganese crusts). Co-chronology of the crusts, paleontological data and $87 \mathrm{Sr} / 86 \mathrm{Sr}$ ratios of the phosphatized substrate indicate that the last phosphatization event in the region happened between 17.6 and 14.6 Ma ago. When the event ceased, oxic conditions were resumed and hydrogenetic crust precipitation started at a maximum rate of $1.6-3.0 \mathrm{~mm} / \mathrm{Ma}$, forming layers of Fe-vernadite above the phosphorites. These crusts differ in composition from crusts that formed prior to the phosphatization, which were impregnated by carbonate fluorapatite and recrystallized forming a $10 \AA \mathrm{Mn}$-phase, in expense of a lower crystallinity Mn-phase. Mn/Fe ratios of non-phosphatized crusts vary from 1.05 to 1.41. The $\mathrm{Mn} / \mathrm{Fe}$ ratios as well as the metal content $(\mathrm{Co}=0.65-1.04 \mathrm{wt} \%, \mathrm{Zn}=0.04-0.06 \mathrm{wt} \%, \mathrm{Cu}=0.02-$ $0.06 \mathrm{wt} \%$ and $\mathrm{Ni}=0.29-0.48 \mathrm{wt} \%$ ) are similar to hydrogenetic crusts described in other parts of the world.
\end{abstract}

\section{Highlights}

- Non-phosphatized Fe-Mn crusts in the region developed above Miocene phosphorites. Phosphatization was probably caused by a Middle Miocene OMZ expansion in depth. Fe-vernadite is the mineral constituent of non-phosphatized Fe-Mn crusts. A stable $10 \AA$-Mn phase is the mineral constituent of phosphatized crusts. Estimated age of the crusts is in agreement with data from NE Atlantic.

Keywords : Rio Grande Rise, Ferromanganese crusts, Atlantic Ocean, Cruzeiro do Sul Lineament, Phosphatization 


\section{Introduction}

28 Ferromanganese crusts and nodules are layered oxide-hydroxides precipitates from

29 seawater that occur in all oceans over the world (Manheim \& Lane-Bostwick, 1989;

30 Hein et al., 1999). There has been an emerging interest about their resource potential for 31 base and strategic metals, such as Co, Rare Earth Elements (REE) and platinum group 32 elements (PGE), because of their possible use in high technology industries and clean 33 energy purposes (Hein et al., 2013). Ferromanganese crusts are also regarded as 34 condensed stratigraphic sections and have been studied to investigate changes in ocean 35 chemistry (Christensen et al., 1997; Ling et al., 1997; Hein et al., 1999; Frank, 2011; 36 Hein \& Koshinsky, 2014).

37 Crusts grow over millions of years in areas of low terrigenous and biogenic sedimentation, where strong currents keep the substrate free from accumulating 39 detrital/biogenic sediments (Hein \& Koschinsky, 2014). Crusts concentrate metals from

40 seawater by sorbing elements through strong coulombic interactions or incorporating 41 them within the structure of iron and manganese oxide-hydroxides (Peacock and 42 Sherman, 2007; Wegorzewski et al., 2020).

43 Hein et al. (1999) showed that the escarpments of seamounts are areas that commonly 44 fulfill the requirements for crust formation. The Geologic Survey of Brazil (CPRM) organized four expeditions to study the geologic history of the Rio Grande Rise (Fig. 1)

46 and investigate the occurrence of ferromanganese crusts on the escarpments of the 47 Cruzeiro do Sul lineament.

48 In this study, petrographic, mineralogical and geochemical data as well as age estimates 49 are presented to show that the Rio Grande Rise region has been favorable for 50 hydrogenetic ferromanganese precipitation after a middle Miocene phosphatization 51 event. These findings are interesting for revealing that the formation of phosphorites 
52 and the ulterior ferromanganese precipitation is coeval with the youngest formation of

53 phosphorites in the Pacific Ocean and in the North Atlantic (Hein et al., 1993; Marino et 54 al., 2017).

\section{Regional Setting}

57 The Rio Grande Rise is a major topographic feature in the western South Atlantic

58 Ocean and occupies a conjugate position relative to the Walvis Ridge, located on the

59 African margin. At the summit of the rise, water depths are as shallow as $800 \mathrm{~m}$, while

60 the surroundings are $4000 \mathrm{~m}$ deep (Fig. 1). The basement of the rise consists of a

61 Coniacian/Santonian tholeiitic basalt overlaid by late Cretaceous and Paleocene

62 sediments (Barker et al. 1981, Thompson et al., 1983; Rohde et al., 2013). Around 46

63 Ma ago, an alkaline magmatism uplifted and exposed the rise above sea level, resulting

64 in a hiatus of pelagic sedimentation (Fodor et al., 1980; Gamboa \& Rabinowitz, 1984;

65 Rohde et al., 2013). After the Eocene, the rise subsided and pelagic sedimentation was

66 resumed. The rise is divided into an eastern (ERGR) and a western (WRGR) part. In

67 contrast to the WRGR, there are only limited data about the ERGR, which is a North-

68 South elongated feature built by an abandoned spreading center (Gamboa \&

69 Rabinowitz, 1984). Both WRGR and ERGR are intercepted by the Cruzeiro do Sul

70 lineament, which is a 30-40 km wide valley trending NW-SE formed as an aborted rift

71 during the rearrangement of tectonic plates close to the Paleogene/Neogene boundary

72 (Mohriak et al., 2010; Galvão \& de Castro, 2017). 


\section{Sample collection}

Samples were collected during legs 1 to 4 of the Geological and Geophysical Expedition to International Waters of the South Atlantic, carried out by the Geological Survey of Brazil (CPRM). Legs were held aboard $R / V$ Marion Dufresne between June and July of 2011. Hundreds of dredging stations were investigated at both WRGR and ERGR, and ferromanganese crust samples described in this study are from 13 different sites along the slopes of Cruzeiro do Sul Lineament (Table 1, Fig. 2). A total of 14 samples were selected among rocks of the dredging stations for chemical characterization and two samples were selected for ${ }^{87} \mathrm{Sr} /{ }^{86} \mathrm{Sr}$ measurements.

\section{Methods}

\subsection{Petrography, Micropaleontology and Electron Probe Micro-analyzer (EPMA)}

Thin sections of the crusts and their substrates were studied under a petrographic microscope for microfossil and mineral identification. Foraminifera were identified in thin sections to the genus level, when possible. Taxonomy of foraminifera specimens was mainly in reference to Blow (1979), Kennett \& Srinivasan (1983) Loeblich \& Tappan (1987) and BouDagher-Fadel (2008). Quantitative spot analyses (WavelengthDispersive X-ray Spectrometry - WDS) of micrometric layers on the ferromanganese crust of sample ML77A was performed in a JEOL JXA 8230 EPMA. Spot analyses were also performed on the substrate of samples ML77A, DC38A, DC25A and DC61B to investigate the composition of the matrix. Analyses were performed using $15 \mathrm{kV}$ voltage, $10 \mathrm{nA}$ current and a spot size beam of $5 \mu \mathrm{m}$. Counting time for all elements was 10 seconds in the peak, and 5 seconds in upper and lower background positions. Analyses were performed at the Electron Microprobe Lab at the University of Brasília. 
994.2 Inductively Coupled Plasma Optical Emission Spectrometry (ICP-OES) and 100 Inductively Coupled Plasma Mass Spectrometry (ICP-MS)

101 Major and trace elements of the ferromanganese crusts were analyzed at Jacobs

102 University Bremen (JUB), Germany, by ICP-OES and ICP-MS. All samples were 103 carefully separated from their substrate, powdered in an agate pan mill and dried at $104105^{\circ} \mathrm{C}$ for $24 \mathrm{~h}$. Immediately after drying, $0.05 \mathrm{mg}$ of each sample was digested with $105 \mathrm{HCl}, \mathrm{HNO}_{3}$ and $\mathrm{HF}$ in a ratio of 3:1:1 ml. Samples in the acid mixture were heated to $106225^{\circ} \mathrm{C}$ for 12 hours in closed vessels that were later opened and kept at $180^{\circ} \mathrm{C}$ for acid 107 evaporation. Digested samples were stored in $0.5 \mathrm{M} \mathrm{HNO}_{3}$ and $0.05 \mathrm{M} \mathrm{HCl}$. Samples 108 were diluted 3.000 times for $\mathrm{Mn}, \mathrm{Fe}, \mathrm{Cu}, \mathrm{Al}, \mathrm{K}, \mathrm{Ca}, \mathrm{Mg}, \mathrm{Na}, \mathrm{P}, \mathrm{V}$ and $\mathrm{Zn}$ measurement 109 using Spectro Ciros Vision (ICP-OES). Determination of Li, Sc, Ti, Co, Ni, Rb, Sr, Y, $110 \mathrm{Zr}, \mathrm{Nb}, \mathrm{Mo}, \mathrm{Te}, \mathrm{Cs}, \mathrm{Ba}, \mathrm{REE}, \mathrm{Hf}, \mathrm{Ta}, \mathrm{W}, \mathrm{Pt}, \mathrm{Pb}$, Th and U was performed in NEX ION 111 350X (ICP-MS), in samples 100.000 times diluted. Certified standard material JMn-1

112 (Ferromanganese nodule from the Geological Survey of Japan) was used for precision 113 and accuracy determination. Detailed description of the methodology, accuracy, 114 precision and interference are in Alexander (2008).

$1164.3 \mathrm{X}$-ray diffractometry (XRD)

117 Mineralogy of the bulk samples was determined using PANalytical X'Pert PRO MPD

$118 \theta-\theta$ diffractometer $(\mathrm{Cu}-\mathrm{K} \alpha$ radiation), with $40 \mathrm{kV}$ and $40 \mathrm{~mA}$ at the German Federal

119 Institute for Geosciences and Natural Resources (BGR), in Hannover. The 120 diffractometer is equipped with a variable divergence slit (20 mm irradiated length) and 121 a Scientific X'Celerator detector (active length $2.122^{\circ}$; phd 60). Samples were scanned 
122 over $5^{\circ}$ to $85^{\circ} 2 \theta$ with a step size of $0.0334^{\circ} 2 \theta$ and a measuring time of $200 \mathrm{sec} / \mathrm{step}$.

123 Afterwards, data were processed using the software High Score Plus.

124 Samples in which a $10 \AA$ A manganese phase was identified in a first analysis underwent a

125 heating treatment $\left(105^{\circ} \mathrm{C}\right.$ for 48 hours $)$ in order to distinguish $10 \AA$ todorokite from 10

$126 \AA$ phyllomanganate. Heating promotes changes in the stacking order of

127 phyllomanganates, but does not affect todorokite (Uspenskaya et al., 1987;

128 Wegorzewski et al., 2015). This happens because upon drying at $105{ }^{\circ} \mathrm{C}$,

129 phyllomanganates lose interlayered water, leading to a collapse of the interlayer and,

130 consequently, to a decrease of the layer-to-layer distance from $10 \AA$ to $7 \AA$ (Uspenskaya

131 et al., 1987).

132

$133 \quad 4.4{ }^{87} \mathrm{Sr} /{ }^{86} \mathrm{Sr}$ ratio measurement

$134{ }^{87} \mathrm{Sr} /{ }^{86} \mathrm{Sr}$ ratios of the substrate on ferromanganese sample HS-145a and on a carbonate

135 vein in sample ML11D were determined through TIMS (Thermal Ionization Mass

136 Spectrometry), in a Finningan MAT 262 at the University of Brasília. Samples were

137 digested in $\mathrm{H}_{3} \mathrm{PO}_{4}$ and the residue kept in a $\mathrm{HNO}_{3}(2.9 \mathrm{~N})$ solution for column

138 chromatography. The solution containing Sr was collected, dried and then dissolved in 1

$139 \mathrm{ml} \mathrm{HNO}_{3}(50 \%)$ for analysis. Procedures followed steps used by Alvarenga et al.

140 (2007). NBS-987 was used as reference material, and yielded a ${ }^{87} \mathrm{Sr} /{ }^{86} \mathrm{Sr}$ ratio of

$1410.71028 \pm 1(1 \sigma)$. 


\section{5. Results}

\section{$144 \quad 5.1$ Morphology of the samples}

145 Through visual description we identified pristine ferromanganese crusts layers (not

146 impregnated with light colored minerals such as phosphates and carbonates), and

147 phosphatized ferromanganese crusts. Pristine samples are laminated or botryoidal and 148 occur in sharp contact above phosphorites (Fig. 3A, 3C, 3D, 3E), volcanic rocks (Fig.

149 3B) or above an older phosphatized crust (Fig. 3G). Phosphatized samples tend to be 150 massive and dense, without clear visible laminae (Fig. 3F, 3G). In phosphatized 151 samples, it is not possible to identify a sharp contact between the dark ferromanganese 152 layers and the substrate because orange and yellowish phosphate aggregates occur 153 within the ferromanganese crust. A summary of crust characteristics is presented in 154 Table 2 and Fig. 3. In Fig. 3A, sample ML77A exhibits a 16 mm-thick non155 phosphatized crust developed around an orange lithified phosphorite. Sample DC61B 156 exhibits a thin crust $(6 \mathrm{~mm})$ precipitated above a vesicular volcanic rock (Fig. 3B). In

157 Fig. 3C, sample DC38A shows a $25 \mathrm{~mm}$-thick non-phosphatized crust with botryoidal 158 texture developed above a white/yellowish lithified phosphorite. Figure 3D shows a 20

159 mm-thick laminated ferromanganese crust above a brownish lithified phosphorite 160 (sample DC25C). Figure 3E shows a 20 mm-thick laminated crust above a phosphorite.

161 Figure 3F shows sample DC25A, which is a mixture of ferromanganese minerals and 162 phosphate. The surface of sample DC25A exhibits botryoidal texture, and only the 163 outermost layer $(1 \mathrm{~mm})$ lacks phosphate stains. Figure $3 \mathrm{G}$ shows a $6 \mathrm{~mm}$-thick crust, 164 with laminated texture, developed above an older and phosphatized crust that contains 165 orange phosphate stains (ML67B). This sample had the non-phosphatized part (the 166 upper $6 \mathrm{~mm}$, ML67B-2) and the phosphatized part analyzed (ML67B-1). 
169 Ferromanganese crusts are opaque to transmitted light and therefore were better

170 observed through electron imaging (Fig. 4). The micrometric layers of the crusts present

171 concave structures (Fig. 4A) of slightly different reflectance (backscattered-electrons

172 image). The sum (wt.\%) of iron, manganese, cobalt, zinc, copper and nickel is lower in

173 darker layers than in lighter layers (Table 3). Figure 4B shows the contact between the

174 crust and its underlying phosphorite (substrate).

5.3 Micropaleontology and EPMA results of the substrate

177 The identification of foraminifera genus was performed in thin sections and focused on

178 providing age constraints for the samples (Table 4). In the substrate of sample ML77A

179 it was possible to identify Discocyclina sp., Nummulites sp. (Fig. 5B) and calcareous

180 structures produced by coralline algae within the phosphatized part, and Orbulina sp.

181 was observed in the non-phosphatized part of the substrate. In sample DC38A (Fig.

182 6A), Orbulina sp. occurs within the phosphorite substrate (Fig. 6B) of the crust, and in

183 the substrate of sample DC25A, we recognized Morozovella sp. (Fig. 6D),

184 Yellow dots shown in Fig. 5 and Fig. 6 are EPMA spot analyses reported in Table 5.

185 EPMA results reveal high phosphorus contents in the substrate of all samples $(>4 \%)$, 186 except in the white fragment of the substrate in sample ML77A, that is composed of 187 calcium carbonate. Among the samples studied in this paper, sample DC61B is the only 188 one that has a volcanic substrate. EPMA analysis on the vesicular glassy matrix also 189 shows a high phosphorus content. 
192 XRD data revealed that non-phosphatized layers of the samples are composed of Fe193 vernadite $\left(\delta-\mathrm{MnO}_{2}\right.$; Fig. 7), which is characterized by two hk0 reflections $(2.45(01) \AA$

194 and $1.45 \AA$ (11)) and no stacking of layers in the crystallographic c* direction. Calcite 195 and quartz may be present to a lesser extent.

196 Older phosphatized samples are composed of a stable $10 \AA$ Mn-phase instead of a Fe197 vernadite. Being stable means that the mineral remains unaffected after a heating 198 treatment at $105^{\circ} \mathrm{C}$ for 48 hours (Fig.8). The heating procedure was carried out to 199 evaluate whether the mineral loses the $10 \AA$ peak, such as phyllomanganates, or not, 200 such as todorokite (Uspenskaya et al., 1987). After the heating procedure, the $10 \AA$ 201 reflex remains stable, which indicates it is todorokite. However, the todorokite 202 reflection at $2.39 \AA$ is missing. In addition, the $10 \AA$ peak does not have the sharpness 203 nor the intensity expected for todorokite under the same analytical conditions. For this

204 reason, we opted for calling this mineral a stable $10 \AA$ Mn phase, instead of todorokite.

205 Carbonate fluorapatite (CFA) and calcite are present in all phosphatized samples.

5.5 Bulk geochemistry

Bulk chemical composition of the 14 analyzed samples is presented in Table 6. Nonphosphatized samples are mainly composed of Fe (17-21 wt.\%) and Mn (20-25\%), while phosphatized samples have lower Fe (10-19 wt.\%) and Mn (6-12 wt.\%) contents.

211 Phosphatized samples are enriched in $\mathrm{P}(>1.5$ wt.\%) and $\mathrm{Ca}(>11.54 \%$ wt.\%), when 212 compared to non-phosphatized samples (Fig. 9), which have low $\mathrm{Ca}(<3.4$ wt.\%) and P 213 (<0.56 wt.\%). Sample DC25C is not phosphatized, but its higher Ca content can be 214 explained by the presence of calcite, not visible in hand sample, but evident in XRD 215 results. 
216 Differences in the composition of the substrate and morphology of the crusts do not

217 affect the chemical composition. Figure 9 compares the $\mathrm{Mn} / \mathrm{Fe}$ ratio and the 218 concentration of selected elements for both phosphatized and non-phosphatized 219 samples. In non-phosphatized samples the Co contents range from 0.65 to 1.04 wt.\%. In 220 phosphatized samples the Co contents are much lower (0.20-0.52 wt.\%). Zn (0.04-0.06 221 wt.\%), $\mathrm{Cu}(0.02-0.05$ wt.\%) and $\mathrm{Ni}(0.26-0.62$ wt.\%) do not have a significant variation

222 between phosphatized and non-phosphatized samples.

223 In the REE spidergram, Y is inserted between Dy and Ho (Fig. 10), based on its ionic 224 radius (Bau \& Dulski, 1995), to allow better comparison with its geochemical twin Ho. 225 Post-Archean Australian Shale (McLennan, 1989) normalized REY patterns show a flat 226 pattern for the samples, with pronounced positive Ce anomaly and negative Y anomaly.

227 Phosphatized crusts have an overall lower content of REE than phosphatized crusts, 228 lower Ce anomaly and a positive Y anomaly. REE contents range between 2167 and 2841 ppm in non-phosphatized crusts, and between 675 and 1576 ppm in phosphatized 230 crusts.

\subsection{Cobalt chronology and growth rates}

232 Growth rate and age estimates were calculated based on Co concentration of the non233 phosphatized samples, following the equation proposed by Puteanus \& Halbach (1988): 234 G.R.=1,28/[Co(\%)-0,24]. The Co flux into ferromanganese crusts is considered to be constant over the entire growth period of the samples (Puteanus \& Halbach, 1988).

236 Thus, the growth rate is correlated to the Co enrichment in each layer. Thus, the higher 237 the growth rate the lower the Co concentration. Co chronometry is an empirical method 238 that matches isotopic determinations, but is unable to measure possible hiatuses during 239 accretion. Hence, growth rates represent maximum values and ages correspond to 240 minimum values. This equation has been used for the past thirty years and has been 
241 proven to provide consistent age estimates by different authors (Josso et al., 2019; Yi et

242 al., 2020).

243 Non-phosphatized samples from the Rio Grande Rise yielded ages between 5 and 16

244 Ma (Table 6), with growth rates ranging from 1.6 to $3.0 \mathrm{~mm} / \mathrm{Ma}$. Co chronometry 245 measurements were performed using the whole thickness of the crusts in all non246 phosphatized samples.

$247 \quad 5.7{ }^{87} \mathrm{Sr} /{ }^{86} \mathrm{Sr}$ indirect dating

$248{ }^{87} \mathrm{Sr} /{ }^{86} \mathrm{Sr}$ analyses on a carbonate vein from sample ML11-D and on the phosphatized 249 substrate of sample HS145a yielded ratios of $0.70860+/-2$ and $0.70880+/-2$ (Fig. 11;

250 Table 7). Comparing the ${ }^{87} \mathrm{Sr} /{ }^{86} \mathrm{Sr}$ ratio of the samples to the curve of the $\mathrm{Sr}$ isotope 251 composition of the oceans through the Cenozoic (McArthur et al., 2012), we suggest 252 that analyzed materials crystalized at 17.6 and $14.6 \mathrm{Ma}$ ago, respectively (Fig. 12). 253 These $\mathrm{Sr}$ isotope ratios represent isotope ratios without an age correction to subtract 254 radiogenic ${ }^{87} \mathrm{Sr}$ produced by internal decay of ${ }^{87} \mathrm{Rb}$ after the time of deposition. 255 Phosphate minerals and calcite have a low ${ }^{87} \mathrm{Rb} /{ }^{86} \mathrm{Sr}$ ratio $(<0.01)$ with a high 256 concentration of unradiogenic Sr (Faure \& Powell., 1972; Faure, 2001). Thus, the age 257 correction is almost negligible for the $\mathrm{Sr}$ isotope. However, data must be interpreted 258 with care because $\mathrm{Sr}$ ages of carbonate and carbonate fluorapatite are susceptible to 259 diagenetic effects: incorporation of Sr during the crystallization of authigenic minerals 260 might drive ages to younger values, but since Co chronology and paleontological data 261 corroborate ${ }^{87} \mathrm{Sr} /{ }^{86} \mathrm{Sr}$ dating, we suggest that diagenetic effects are negligible in our 262 samples.

\section{6. Discussion}


265 The mineralogy of non-phosphatized samples is dominated by Fe-bearing vernadite ( $\delta$ -

$\left.266 \mathrm{MnO}_{2}\right)$, possibly intergrown with amorphous iron oxyhydroxide $(\delta$-FeOOH$)$

267 nanoparticles (Koschinsky et al., 2010). This is typical of seawater-sourced precipitates

268 that formed under oxic conditions. In phosphatized samples the Mn-phase is the initial

269 transformation from a layered manganate into a tunnel structure, but without a perfect

$2703 \times 3$ octahedra tunnel structure. It probably corresponds to a distorted structure of

271 todorokite, transitioning from very low crystallinity Fe-vernadite. This phase has both

$27210 \AA$ and $4.8 \AA$ reflections, but lacks the characteristic $2.39 \AA$ reflex of todorokite.

273 Instead, it has the typical peaks of phyllomanganates (vernadite, $2.44 \AA$ and $1.42 \AA$ ).

274 The $\mathrm{Mg}$ contents in these samples (1.85 - $1.97 \mathrm{wt} \%)$ is lower than expected for

275 minerals diagenetically transitioning to todorokite (Manceau et al., 2014), which have

276 around 4 wt.\% of $\mathrm{Mg}$. Therefore, the manganate of phosphatized samples will be

277 reported as stable $10 \AA$ Mn-phase, and not as typical todorokite. This $10 \AA$-Mn phase

278 shows high amounts of incorporated $\mathrm{Zn}, \mathrm{Cu}$ and $\mathrm{Ni}$, but low $\mathrm{Co}$ contents, which is 279 characteristic for suboxic enrichment (Manceau et al., 2014) and was also reported by

280 Koshinsky et al. (1997) in phosphatized samples. In vernadite, Mn occurs in oxidation

281 state +4 , while $10 \AA-M n$ oxides contain $\mathrm{Mn}$ of less oxidated states, which also

282 demonstrates the suboxic character of the environment in which the $10 \AA$-Mn phase 283 crystallized.

6.2 Classification and age of crusts

286 Ferromanganese crusts precipitated above phosphorites plot within the hydrogenetic

287 field of the ternary diagram Fe-Mn-10*(Ni+Cu+Co) (Fig.13; Bonatti et al., 1972). They

288 also plot within the hydrogenetic fields of $\mathrm{Y}_{\mathrm{SN}} / \mathrm{Ho}_{\mathrm{SN}}$ vs $\mathrm{Ce}_{\mathrm{SN}} / \mathrm{Ce}_{\mathrm{SN}^{*}}{ }^{*}$ and $\mathrm{Nd}$ vs

$289 \mathrm{Ce}_{\mathrm{SN}} / \mathrm{Ce}_{\mathrm{SN}} *$ diagrams (Fig. 14) proposed by Bau et al. (2014). These diagrams are not 
appropriate to classify phosphatized samples because their chemical composition was

291 altered during phosphatization.

292 Considering (i) the presence of Orbulina sp. (Kennett \& Srinivasan, 1983) on the

293 phosphorites, which first occurrence was 15.1 Ma ago; (ii) the indirect dating of the

294 substrate through ${ }^{87} \mathrm{Sr} /{ }^{86} \mathrm{Sr}$ ratios (14.6-17.6 Ma); and (iii) the age of the ferromanganese

295 crusts calculated with Co chronology (5-16 Ma), we suggest that the phosphatization

296 event occurred between 14.6 and 17.6 Ma ago and once it ceased, crust precipitation

297 was resumed. These ages are in agreement with ages reported by González et al. (2016)

298 for the last phosphatization event in the Galicia Bank, NE Atlantic (18.5 - 17.7 Ma).

299 The presence of the $10 \AA$ Mn-phase in older crusts can be explained by the

300 recrystallization of a less ordered manganate phase during the phosphatization. The

301 event of phosphatization also caused the impregnation of preexisting sediments with

302 carbonate fluorapatite and possibly was a period of no crust precipitation, due to the

303 suboxic condition of phosphate-rich waters.

304 The estimated ages of the crusts are in agreement with ages reported by Benites et al.

305 (2020), who studied ferromanganese crusts from the summit of the Rio Grande Rise. In

306 a sample from the São Paulo Plateau (Fig. 1), located $500 \mathrm{~km}$ eastwards from the Rio

307 Grande Rise and at a $2781 \mathrm{~m}$ water depth, Goto et al. (2017) suggested favorable

308 environmental conditions for crust precipitation during the last $30 \mathrm{Ma}$. However,

309 different from the Rio Grande Rise, there is no evidence of phosphatization during the

310 growth interval of the studied sample. In another sample from the São Paulo Plateau,

311 Nozaki et al. (2017) dated the base of a ferromanganese crust at ca. 5 Ma.

312

$313 \quad 6.3$ The REY composition of the crusts 
314 The positive Ce anomaly is common in hydrogenetic ferromanganese crusts, because

315 Ce is redox-sensitive and oxidizes after sorption at the oxyhydroxide surface from

316 dissolved Ce(III) to insoluble Ce(IV) (Bau et al., 1996; Bau \& Koschinsky, 2009).

317 The phosphatization process occurs under sub-oxic conditions, $\mathrm{Ce}$ is reduced and

318 remobilized. Thus, phosphatized samples do not have positive Ce anomalies of the same

319 extent as non-phosphatized samples. In non-phosphatized samples, the calculated Ce

320 anomaly $\mathrm{Ce}_{\mathrm{SN}} / \mathrm{Ce}_{\mathrm{SN}} *=\mathrm{Ce}_{\mathrm{SN}} /\left(0.5 \mathrm{La}_{\mathrm{SN}}+0.5 \mathrm{Pr}_{\mathrm{SN}}\right)$ varies from 2.3 to 3.4 , while in non-

321 phosphatized crusts values drop to 1.7-3.0.

322 The negative Y anomaly of non-phosphatized crusts is not controlled by the redox state,

323 but by the strength of surface complexes (Bau \& Dulski, 1994). Ho and Dy form

324 stronger surface-complexes than $\mathrm{Y}$ on ferromanganese precipitates. Thus, as the surface

325 complex of $\mathrm{Y}$ is less stable, there is a decoupling of $\mathrm{Y}$ and Ho that drives negative $\mathrm{Y}$ 326 anomalies in the REY pattern (Bau \& Dulski, 1994; Bau et al, 1996). In contrast,

327 phosphatized samples have a positive $\mathrm{Y}$ anomaly because the impregnation of 328 phosphate in the pores of ferromanganese crusts imprints a seawater-like composition to 329 the samples. The positive $\mathrm{Y}$ anomaly in phosphatized crusts is caused by the 330 introduction of $\mathrm{Y}$ during the crystallization of stable phosphate phases (Koschinsky et 331 al., 1997). The calculated negative $\mathrm{Y}$ anomaly $\mathrm{Y}_{\mathrm{SN}} / \mathrm{Y}_{\mathrm{SN}} *=\mathrm{Y}_{\mathrm{SN}} /\left(0.5 \mathrm{Dy}_{\mathrm{SN}}+0.5 \mathrm{Ho} \mathrm{SN}\right)$ is $332 \quad 0.5-0.9$ in non-phosphatized and 0.9-1.4 in phosphatized samples.

333 Figure 15 exhibits $\mathrm{Ce}_{\mathrm{SN}} / \mathrm{Ce}_{\mathrm{SN}} *$ vs $\mathrm{La}_{\mathrm{SN}} / \mathrm{Lu}_{\mathrm{SN}}$ graphic, where the difference in REE

334 behavior between phosphatized crusts and non-phosphatized crusts is shown. Carbonate

335 fluorapatite is more enriched in MREE and HREE than Fe-Mn oxides, as a result $336 \mathrm{La}_{\mathrm{SN}} / \mathrm{Lu}_{\mathrm{SN}}$ ratio of phosphatized samples is lower than the ratio of non-phosphatized 337 samples. 
6.4 Aspects of subsidence and ocean circulation

340 The presence of photosynthetic algae structures (Coralline algae) and large benthic

341 foraminifera specimens (Discocyclina sp. and Nummulites sp.) in the phosphatized

342 substrate of sample ML77A indicates an Eocene age for the assemblage and it is

343 characteristic of shallow waters. These data evidence the Eocene uplift of the rise

344 (Gamboa \& Rabinowitz, 1984). Younger assemblages in which Orbulina sp. occurs are

345 dominated by planktic foraminifera and lack photosynthetic specimens, indicating

346 greater water depths since the Miocene.

347 The $\mathrm{Zr} / \mathrm{Hf}$ ratio (Schmidt et al., 2014) as well as Y/Ho ratio (Bau et al., 1995; Censi et

348 al., 2007) are interesting tracers of water masses. Crusts from the Pacific Ocean were

349 expected to have higher $\mathrm{Zr} / \mathrm{Hf}$ and $\mathrm{Y} / \mathrm{Ho}$ ratios than crusts from the Atlantic, because $\mathrm{Hf}$

350 and Ho have a particle reactive behavior and are preferentially removed from the water

351 through the ocean conveyor belt, with respect to their geochemical twin. However, only

$352 \mathrm{Zr} / \mathrm{Hf}$ ratios behave as expected (Fig. 16), while Y/Ho values are very similar in

353 Atlantic and Pacific samples. Thus, we suggest that the higher $\mathrm{Zr} / \mathrm{Hf}$ ratios of Pacific

354 crusts are a consequence of Hf removal through time during ocean circulation. Rickli et

355 al. (2009) suggest Hf is preferentially removed from seawater by adsoption on biogenic 356 opal. The interaction with opal rich waters (e.g. Southern Ocean) on the Strait of

357 Magellan could be one possible explanation for the difference in $\mathrm{Zr} / \mathrm{Hf}$ ratios of samples

358 from the two oceans. Y/Ho ratios are very similar in Pacific and Atlantic crust samples

359 possibly because the weak complexation of $\mathrm{Y}$ is a ubiquitous feature in ferromanganese

360 crusts that overprints a possible effect of different water masses.

362 6.4 Comparison with ferromanganese crusts from Northeast Atlantic 
363 Ferromanganese crusts from the Canary Islands, on the East Atlantic, present

364 anomalous contents of $\mathrm{Fe}$ and $\mathrm{Al}$, due to their proximity to the continental crust, eolian

365 input and authigenic formation of phyllosilicates (Hein et al., 2000; Marino et al.,

366 2017). This is not observed in crusts from the Rio Grande Rise, because they

367 precipitated far enough from the continent. However, the formation of crusts in both

368 areas of the Atlantic is coeval and a phosphatization event is also recorded by samples

369 from the Canary Islands (Marino et al., 2017). Koschisnky et al. (1996) investigated

370 ferromanganese samples from other two seamounts in the Northeast Atlantic (Lion and

371 Tropical seamounts), and show that the age of the crusts in these seamounts is very

372 similar to ages estimated in this paper (ca. $12 \mathrm{Ma}$ ), but the phosphatization event dated

373 by Koschinsky et al. (1996) might be as old as 30-40 Ma.

374

$375 \quad 6.5$ Causes of phosphatization

376 The phosphatization of ferromanganese crusts and the formation of phosphorites on

377 seamounts is generally associated with changes in climatic conditions and with the

378 spreading of phosphate-rich sub-oxic waters throughout the ocean (Halbach et al., 1982,

379 1989; Hein et al., 1993; Hyeong et al., 2013). Halbach et al. (1982, 1989) proposed that

380 the phosphatization on seamounts is caused by the expansion of oxygen minimum zones

381 (OMZ) as a result of increased productivity in surface waters. This process would have

382 expanded the limits of $\mathrm{OMZ}$ at depth, making it reach the top of seamounts and

383 impregnating sediments with phosphorous. Kraal et al. (2012) show that in the Arabian

384 Sea, authigenic formation of calcium-phosphate minerals occurs where the OMZ

385 intersects the seafloor topography. However, they also show that a large fraction of

386 phosphates is not authigenic and was deposited from the water column. 
387 Other authors suggest that phosphorus-rich waters may have accumulated in deep areas

388 of the ocean during periods of sluggish circulation, and later, during normal circulation

389 conditions, upwelled on the edge of seamounts (Hein et al., 1993).

390 Our data do not allow constraining further details about the source of the phosphorous-

391 rich waters that caused the phosphogenesis in the RGR. However, comparing our

392 samples to the sample from the São Paulo Plateau (Goto et al., 2017), we observed that

393 all our crusts are either phosphatized or precipitated above a phosphorite and are from

394 shallower sites (688-1798 m) than the sample from the São Paulo Plateau (2871 m), that

395 is not phosphatized. Thus, we suggest that the expanded OMZ is most likely the source

396 of phosphorous. We do not discard the hypothesis that this event overprinted multiple

397 phosphatization events that happened prior to the Miocene.

\section{Summary and conclusions}

399 Ferromanganese crusts that precipitated above phosphate-rich substrates (phosphorites,

400 phosphate-impregnated volcanic rocks and older phosphatized ferromanganese crusts)

401 on the Rio Grande Rise grew after a middle Miocene phosphatization event that was

402 responsible for recrystallizing older crusts and impregnating sediments with carbonate

403 fluorapatite.

404 Crusts that formed after the phosphatization are composed of Fe-vernadite, which is a

405 phyllomanganate, typical of hydrogenetic precipitates under oxic conditions. Instead of

406 vernadite, older crusts affected by the phosphatization have a stable $10 \AA$ Mn-phase,

407 which is a product of recrystallization of a less ordered Mn-phase under sub-oxic

408 conditions during the phosphatization event.

409 All non-phosphatized crusts yielded Co chronometric minimum ages between 5 and 16

410 Ma, with maximum growth rates ranging from 1.6 to $3.0 \mathrm{~mm} / \mathrm{Ma}$. Marino et al. (2017)

411 showed that ferromanganese crusts from the Northeast Atlantic Ocean were also 
412 affected by phosphatization in the Miocene. Applying more precise dating methods in

413 the crusts and their substrates will allow better interpretations regarding the

414 paleoceanography through the Neogene-Quaternary in the region, and may provide

415 insightful data on Miocene ocean chemistry and its response to climate changes.

416

417 Acknowledgments

418 The authors acknowledge the Geochemistry Lab at Jacobs University and the

419 Geochronology Lab at the University of Brasília. The authors thank James Hein for the

420 discussions and Imogen Browne for the kind suggestions. The project was funded by

421 IODP/CAPES Brazil 38/2014 and CAPES/CNPq (88881.188635/2018-01). The project

422 was developed in collaboration with the Geological Survey of Brazil (CPRM).

\section{References}

424 Alexander, B., 2008. Trace element analyses in geological materials using low resolution ICPMS. Jacobs University

425 Technical Reports, 18, 1-78. Available at: http://nbn-resolving.org/urn:nbn:de:gbv:579-opus-1006789.

426 Alvarenga, C.J.S., Della Giustina, M.E.S., Santos, R.V., Gioia, S., Guimarães, E.M., Dardenne, M.A., 2007.

427 Variações dos isótopos de C e Sr em carbonatos pré e pós-glaciação Jequitaí (Esturtiano) na região de Bezerra-

428 Formosa, Goiás. Revista Brasileira de Geociências, 37, 999-1007.

429 Barker P.F., Carlson R.L., Johnson, D.A., Cepek, P., Coulbourn, W.,Gamboa, L.A., Hamilton, N., Melo, U., Pujol, 430 C., Shor, A.N., Suzyumov, A.E., Tjalsma, L.R.C., Walton, W.H., Weiss, W., 1981. Deep Sea Drilling Project Leg 72: 431 Southwest Atlantic paleocirculation and Rio Grande Rise tectonics. Geological Society of America Bulletin, 92, 294432309.

433 Bau, M., Koschinsky, A., Dulski, P., Hein, J.R., 1996. Comparison of the partitioning behaviours of yttrium, rare 434 earth elements, and titanium between hydrogenetic marine ferromanganese crusts and seawater. Geochimica et 435 Cosmochimica Acta, 60(10), 1709-1725.

436 Bau, M., Dulski, P., 1995. Comparative study of yttrium and rare-earth element behaviours in fluorine-rich 437 hydrothermal fluids. Contributions to Mineralogy and Petrology, 119, 213-223.

438 Bau M., Dulski P., Môller, P., 1995. Yttrium and holmium in South Pacific seawater: Vertical distribution and 439 possible fractionation mechanisms. Chemie der Erde, 55, 1-15.

440 Bau, M., Dulski, P., 1994. Evolution of the yttrium-holmium systematics of seawater through time. Mineralogical 441 Magazine - Goldschmidt Conference Abstracts, 58A, 61-62. 
Bau, M., 1996. Controls on the fractionation of isovalent trace elements in magmatic and aqueous systems: evidence from Y/Ho, Zr/Hf, and lanthanide tetrad effect. Contributions to Mineralogy and Petrology, 123, 323-333

Bau, M., Koschinsky, A., 2009. Oxidative scavenging of cerium on hydrous Fe oxide: Evidence from the distribution of rare earth elements and yttrium between $\mathrm{Fe}$ oxides and $\mathrm{Mn}$ oxides in hydrogenetic ferromanganese crusts. Geochemical Journal., 43(1), 37-47.

Bau, M., Schmidt, K., Hein, J.R., Kuhn, T., Usui, A., 2014. Discriminating between different genetic types of marine ferro-manganese crusts and nodules based on rare earth elements and yttrium. Chemical Geology, 381, 1-9. Available at: http://dx.doi.org/10.1016/j.chemgeo.2014.05.004.

Benites, M., Hein, J.R., Mizell, K., Blackburn, T., Jovane, L., 2020. Genesis and Evolution of Ferromanganese Crusts

451 from the Summit of Rio Grande Rise, Southwest Atlantic Ocean. Minerals, 10, 349.

452 Blow, W.H., The Cainozoic Globigerinida., 1979. E.J. Brill, Leiden.

453 Bonatti, E., Kraemer, T., Rydell, H., 1972. Classification and genesis of submarine ironmanganese deposits. In: Horn, 454 D.R. (Ed.), Ferromanganese Deposits of the Ocean Floor. Arden House, New York, 149-165.

455 BouDagher-Fadel, M.K. Evolution and Geological Significance of Larger Benthic Foraminifera., 2008. UCL Press, 456 London.

457 Censi, P., Zuddas, P., Larocca, D., Saiano, F., Placenti, F., Bonanno, A., 2007. Recognition of water masses 458 according to geochemical signatures in the Central Mediterranean sea: Y/Ho ratio and rare earth element behavior. 459 Chemistry and Ecology, 23(2), 139-155.

460 Christensen, J.N., Halliday, A.N., Godfrey, L.V., Hein, J.R., Rea, D.K., 1997. Climate and ocean dynamics and the

461 lead isotopic records in Pacific ferromanganese crusts. Science, 277, 913.

462 Constantino, R.R., Hackspacher, P.C., de Souza, I.A., Costa, I.S.L., 2017. Basement structures over Rio Grande Rise 463 from gravity inversion. J. S. Am. Earth Sci., 75, 85-91.

464 Faure, G., 2001. Origin of Igneous Rocks - The Isotopic Evidence. Springer-Verlag, Heidelberg. 496 pp.

465 Faure, G., Powell, J.L., 1972. Strontium Isotope Geology. 188 pp. Springer-Verlag, Berlin, Heidelberg, New York.

466 Flower, B.P., Kennett, J.P., 1994. The middle Miocene climatic transition: East Antarctic ice sheet development, 467 deep ocean circulation and global carbon cycling. Palaeogeogr. Palaeoclimatol. Palaeoecol., 108(3-4):537-555.

468 https://doi.org/10.1016/0031-0182(94)90251-8

469 Fodor, R.V., Kumar, N., Bornhorst, T.J., Husler, J.W., 1980. Petrology of basaltic rocks from the São Paulo ridge, 470 southwestern Atlantic Ocean. Mar. Geol., 36(1-2), 127-141.

471 Frank M. 2011. Oceanography: chemical twins, separated. Nat. Geosci. 4, 220-221.

472 Futa, K., Peterman, Z.E., Hein, J.R., 1988. Sr and Nd isotope variations in ferromanganese crust from the Central 473 Pacific: implications for age and source provenance, Geochimica et Cosmochimica Acta, 52, 2229-2233.

474 Galvão, I.L.G. de Castro, D.L., 2017. Contribution of global potential field data to the tectonic reconstruction of the 475 Rio Grande Rise in the South Atlantic. Marine and Petroleum Geology, 86, 932-949.

476 Gamboa, L.A.P., Rabinowitz, P.D., 1984. The evolution of the Rio Grande Rise in the southwest Atlantic Ocean. 477 Mar. Geol., 58(1-2), 35-58.

478 Gioia, S.M.C.L., Pimentel, M.M., 2000. The Sm-Nd isotopic method in the geochronology laboratory of the 479 University of Brasília. An. Acad. Bras. Ciênc., 72(2), 219-245. 

Geochemistry. Springer-Verlag, Berlin Heidelberg, 2006. 371-427.

González, F.J., Somoza, L., Hein, J.R., Medialdea, T., León, R., Urgorri, V., Reyes, J., Martín-Rubí, J.A., 2016. Phosphorites, Co-rich Mn nodules, and Fe-Mn crusts from Galicia Bank, NE Atlantic: reflections of Cenozoic tectonics and paleoceanography. Geochem.Geophys. Geosyst. 17. http://dx.doi.org/10.1002/2015GC005861.

Goto, K.T., Nozaki, T., Toyofuku, T., Augustin, A.H., Shimoda, G., Chang Q., Kimura, J.I., Kameo, K., Kitazato, H., Suzuki, K., 2017. Paleoceanographic conditions on the São Paulo Ridge, SW Atlantic Ocean, for the past 30 million years inferred from $\mathrm{Os}$ and $\mathrm{Pb}$ isotopes of a hydrogenous ferromanganese crust. Deep-Sea Research Part II: Topical Studies in Oceanography, 146, 82-92.

489 Grau, R., Kudrass, H.R., 1991. Pre-Eocene and younger manganese crusts from the Manihiki Plateau, southwest Pacific Ocean. Mar. Mining., 10, 231-246.

Halbach, P., Manheim, F.T., Otten, P., 1982. Co-rich ferromanganese deposits in the marginal seamount regions of the central Pacific basin - results of the Midpac '81. Erzmetall., 35, 447-453.

493 Halbach, P., Sattler, C.D., Teichmann, F., Washner, M., 1989. Cobalt-rich and platinum-bearing manganese crust deposits on seamounts: nature, formation, and metal potential. Mar. Mining, 8, 23-39.

495 Halbach, P., Kriete, C., Pause, B., Puteanus, D., 1989. Mechanisms to explain the platinum concentration in 496 ferromanganese seamount crusts. Chemical Geology, 76 (1-2), 96-106.

497 Hein, J.R., Koschinsky, A., Bau, M., Manheim, F.T., Kang, J.-K., Roberts, L. Cobalt-Rich Ferromanganese Crusts in 498 the Pacific. In: Cronan, D.S. (Ed.). Handbook of Marine Mineral Deposits. CRC Press, Boca Raton, FL. 1999. 239499281.

500 Hein, J.R., Koschinsky, A., 2014. Deep-ocean ferromanganese nodules and crusts. In: Holland, H.D., Turekian, K.K. 501 (Eds.), Treatise on Geochemistry. 2nd Edition. Elsevier, Oxford, pp. 273-291.

502 Hein, J.R., Koschinsky, A., Halliday, A.N., 2003. Global occurrence of tellurium-rich ferromanganese crusts and a 503 model for the enrichment of tellurium. Geochimica et Cosmochimica Acta, 67(6), 1117-1127.

504 Hein, J.R., Mizell, K., Koschinsky, A., Conrad, T.A., 2013. Deep-ocean mineral deposits as a source of critical 505 metals for high- and green-technology applications: comparison with land-based resources. Ore Geol. Rev., 51, 1-14. 506 http://dx.doi.org/10.1016/j.oregeorev.2012.12.001.

507 Hein, J.R., Yeh, H.W., Gunn, S.H., Sliter, W.V., Benninger, L.M., Wang, C.H., 1993. Two Major Cenozoic Episodes

508 of Phosphogenesis Recorded in Equatorial Pacific Seamount Deposits. Paleoceanography, 8, 293-311.

509 Hyeong, K., Kim, J., Yoo, C.M., Moon J.-W., Seo, I., 2013. Cenozoic history of phosphogenesis recorded in the 510 ferromanganese crusts of central and western Pacific seamounts: Implications for deepwater circulation and 511 phosphorus budgets. Palaeogeogr. Palaeoclimatol. Palaeoecol., 392, 293-301.

512 Josso, P., Parkinson, I. Horstwood, M., Lusty, P., Chenery, S., Murton, B., 2019. Improving confidence in 513 ferromanganese crust age models: A composite geochemical approach. Chemical Geology, 513, 108-119.

514 Kashiwabara, T., Oishi, Y., Sakaguchi, A., Sugiyama, T., Usui, A., Takahashi, Y., 2014. Chemical processes for the 515 extreme enrichment of tellurium into marine ferromanganese oxides. Geochimica et Cosmochimica Acta, 131, 150516163. 
517 Kennett, J.P., 1977. Cenozoic evolution of Antarctic glaciation, the circum-Antarctic Ocean, and their impact on

518 global paleoceanography. Journal of Geophysical Research: Oceans and Atmospheres, 82(27): 3843-3860.

519 https://doi.org/10.1029/JC082i027p03843

520 Kennett, J.P., Srinivasan, M.S., 1983. Neogene Planktonic Foraminifera: A Phylogenetic Atlas. Stroudsburg, PA 521 (Hutchinson Ross).

522 Koschinsky A., Halbach P., 1995. Sequential leaching of marine ferromanganese precipitates: genetic implications.

523 Geochimica et Cosmochimica Acta, 59, 5113-5132.

524 Koschinsky A., Halbach P., Hein, J.R., Mangini, A., 1996. Ferromanganese crusts as indicators for 525 paleoceanographic events in the NE Atlantic. Geol. Runsch., 85, 567-576.

526 Koschinsky A., Stascheit A., Bau M., Halbach P., 1997. Effects of phosphatization on the geochemical and 527 mineralogical composition of marine ferromanganese crusts. Geochimica et Cosmochimica Acta, 61, 4079-4094.

528 Koschinsky, A., Bau, M., Marbler, H., Schmidt, K., 2010. Rare valuable metals in marine ferromanganese nodules 529 contents and accumulation processes. Zeitschrift für Angewandte Geologie, 51 (2), 33-39.

530 Lacasse, C.M., Santos, R.V., Dantas, E.L., Vigneron, Q., de Sousa, I.M.C., Harlamov, V., Lisniowski, M.A., 531 Pessanha, I.B.M., Frazão, E.P., Cavalcanti, J.A.D., 2017. ${ }^{87} \mathrm{Sr} /{ }^{86} \mathrm{Sr}$ dating and preliminary interpretation of magnetic 532 susceptibility logs of giant piston cores from the Rio Grande Rise in the South Atlantic. J. S. Am. Earth Sci., 80, 244533254

534 Ling, H.F., Burton, K.W., O'Nions, R.K., Kamber, B.S., von Blanckenburg, F., Gibb, A.J., Hein, J.R., 1997. 535 Evolution of $\mathrm{Nd}$ and $\mathrm{Pb}$ isotopes in central Pacific sea water from ferromanganese crusts. Earth and Planetary Science 536 Letters, 146(1-2), 1-12.

537 Loeblich, A.R., Tappan, H. Foraminiferal Genera and their Classification., 1987. Van Nostrand Reinhold Company, 538 New York. 970pp.

539 Manceau, A., Lanson, M., Takahashi, Y., 2014. Mineralogy and crystal chemistry of Mn, Fe, Co, Ni and Cu in a 540 deep-sea Pacific polymetallic nodule. Am. Mineral., 99, 2068-2083.

541 Manheim, F. T., Lane-Bostwick, C. M., 1989. Chemical composition of ferromanganese crusts in the world ocean: a

542 review and comprehensive database, U.S. Geological Survey Open File Report 89-020, 200 pp.,

543 Marino, E., González, F.J., Somoza, L., Lunar, R., Ortega, L., Vázquez, J.T., Reyes, J., Bellido, E., 2017. Strategic 544 and rare elements in Cretaceous-Cenozoic cobalt-rich ferromanganese crusts from seamounts in the Canary Island 545 Seamount Province (northeastern tropical Atlantic). Ore Geol. Rev., 87, 41-61. Available at: 546 http://dx.doi.org/10.1016/j.oregeorev.2016.10.005.

547 McLennan, S.M., 1989. Rare earth elements in sedimentary rocks; influence of provenance and sedimentary 548 processes. Reviews in Mineralogy and Geochemistry, 21(1), 169-200.

549 Mohriak, W., Nóbrega, M., Odegard, M.E., Gomes, B.S. Dickson, W.G., 2010. Geological and geophysical 550 interpretation of the Rio Grande Rise, south-eastern Brazilian margin: Extensional tectonics and rifting of continental 551 and oceanic crusts. Petrol. Geosci., 16, 231-245.

552 Nozaki, T., Takaya, Y., Toyofuku, T., Tokumaru, A., Goto, K.T., Chang, Q., Kimura, J.I., Kato, Y., Suzuki, K., 553 Augustin, A.H., Kitazato, H., 2017. Depositional Age of a Fossil Whale Bone from São Paulo Ridge, South Atlantic

554 Ocean, Based on Os Isotope Stratigraphy of a Ferromanganese Crust. Resour. Geol., 67, 442-450. 
Peacock, C.L., Sherman, D.M., 2007. Crystal chemistry of Ni in marine ferromanganese crusts and nodules. American Mineralogist, 92, 1087-1092.

Piepgras, D.J., Wasserburg, G.J., 1987. Rare earth element transport in the western North Atlantic inferred from Nd isotope observations, Geochimica et Cosmochimica Acta, 51, 1257-1271.

559 Puteanus, D., Halbach, P., 1988. Correlation of Co concentration and growth rate - a method for age determination 560 of ferromanganese crusts. Chemical Geology, 69 (1-2), 73-85. http://dx.doi.org/10.1016/0009-2541(88)90159-3.

561 Reynolds, B.C., Frank, M., O’Nions, R.K., 1999. Nd- and Pb-isotope time series from Atlantic ferromanganese 562 crusts: implications for changes in provenance and paleocirculation over the last 8 Myr. Earth Planet. Sci. Lett. 173, 381-396.

564 Rickli J., Frank M., Halliday A.N., 2009. The hafnium-neodymium isotopic composition of Atlantic seawater. Earth

565 Planet. Sci. Lett., 280, 118-127.

566 Rohde, J.K., van den Bogaard, P., Hoernle, K., Hauff, F., Wener, R., 2013. Evidence for an age progression along the

567 Tristan-Gough volcanic track from new ${ }^{40} \mathrm{Ar} /{ }^{39} \mathrm{Ar}$ ages on phenocryst phases. Tectonophysics, 604, 60-71.

568 Rutgers v.d. Loeff, M., Geibert, W., 2008. U- and Th-Series Nuclides as Tracers of Particle Dynamics, Scavenging 569 and Biogeochemical Cycles in the Oceans. In: Krishnaswami, S., Kirk Cochran, J. (Eds.), Radioactivity in the 570 environment. Elsevier, Amsterdam, pp. 227-268.

571 Schmidt, K., Bau, M., Hein, J.R., Koschinsky, A., 2014. Fractionation of the geochemical twins Zr-Hf and Nb-Ta 572 during scavenging from seawater by hydrogenetic ferromanganese crusts. Geochimica et Cosmochimica Acta, 140, 573 468-487. Available at: http://dx.doi.org/10.1016/j.gca.2014.05.036.

574 Stichel, T., Frank, M., Rickli, J., Haley, B.A., 2012. The hafnium and neodymium isotope composition of seawater in the Atlantic sector of the Southern Ocean. Earth Planet. Sci. Lett., 317-318, 282-294.

576 Thompson, G., Humphris, S. E., Schilling, J., 1983. Petrology and geochemistry of basaltic rocks from Rio Grande

577 Rise, South Atlantic; Deep Sea Drilling Project Leg 72, Hole 516F. Initial Reports of the Deep Sea Drilling Project, 578 Vol. 72, p.457-466. doi:10.2973/dsdp.proc.72.115.1983

579 Uspenskaya, T.Y., Gorshkov, A.I., Sivtsov, A. V., 1987. Mineralogy and Internal Structure of Fe-Mn Nodules from 580 the Clarion-Clipperton Fracture Zone. Int. Geol. Rev., 29(3), 363-371.

581 Wedepohl, K.H., 1995. The composition of the continental-crust. Geochimica et Cosmochimica Acta, 59(7), 12175821232.

Wegorzewski, A.V., Kuhn, T., Dohrmann, R., Wirth, R., Grangeon, S., 2015. Mineralogical characterization of individual growth structures of Mn-nodules with diferente $\mathrm{Ni}+\mathrm{Cu}$ content from the central Pacific Ocean. Am. Mineral., 100, 2497-2508.

587 Wegorzewski, A.V., Kuhn, T., 2014. The influence of suboxic diagenesis on the formation of manganese nodules in 588 Clarion Clipperton nodule belt of the Pacific Ocean. Mar. Geol., 357, 123-138.

589 Wegorzewski, A.V., Grangeron, S., Webb, S.M., Heller, C., Kuhn, T., 2010. Mineralogical transformations in 590 polymetallic nodules and the charge of $\mathrm{Ni}, \mathrm{Cu}$ and $\mathrm{Co}$ crystal-chemistry upon burial in sediments. Geochimica et 591 Cosmochimica Acta, 282, 19-37.

592 Yi, L., Medina-Elizalde, M., Kletetschka, G., Yao, H., Simon, Q., Paterson, G., Bourlès, D., Deng, X., Du, J., Qin, 593 H., Chen, Y., Xie, Q., Xiao, J., Wang, Y., Andreucci, C., Keddadouche, K., Aumaître, G., Liu, Y., Wang, H., Zhu, 594 R., 2020. The potential of marine ferromanganese nodules from Eastern Pacific as recorders of Earth's magnetic field 
595 changes during the past 4.7 Myr: a geochronological study by magnetic scanning and authigenic 10Be/9Be dating.

596 Journal of Geophysical Research: Solid Earth. 10.1029/2019JB018639.

597 


\section{TABLES}

600 Table 1: Coordinates and water depth from dredging stations.

\begin{tabular}{ccccccccc}
\hline & \multicolumn{7}{c}{ Dredging initial and final coordinates } \\
\hline $\begin{array}{c}\text { Dredging } \\
\text { Station }\end{array}$ & Leg & $\begin{array}{c}\text { Sample } \\
\text { prefix }\end{array}$ & $\begin{array}{c}\text { Initial } \\
\text { depth }(\mathrm{m})\end{array}$ & $\begin{array}{c}\text { Final } \\
\text { depth }(\mathrm{m})\end{array}$ & $\begin{array}{c}\text { Initial } \\
\text { Latitude (S) }\end{array}$ & $\begin{array}{c}\text { Initial } \\
\text { Longitude (W) }\end{array}$ & $\begin{array}{c}\text { Final } \\
\text { Latitude (S) }\end{array}$ & $\begin{array}{c}\text { Final } \\
\text { Longitude (W) }\end{array}$ \\
\hline ERG 064 & 1 & ML64 & 1105 & 995 & 30.811120 & 35.172832 & 30.820700 & 35.178700 \\
ERG 039 & 1 & ML39 & 830 & 800 & 31.148266 & 35.223911 & 31.159890 & 35.214233 \\
ERG 011 & 1 & ML11 & 990 & 950 & 30.495476 & 36.302307 & 30.486013 & 36.302361 \\
ERG 067 & 1 & ML67 & 1000 & 950 & 31.045689 & 35.711288 & 31.048300 & 35.710900 \\
ERG 075 & 1 & ML75 & 1440 & 1376 & 30.318943 & 36.479797 & 30.332474 & 36.485876 \\
ERG 077 & 1 & ML77 & 1542 & 1200 & 30.096700 & 36.827300 & 30.104900 & 36.827600 \\
ERG 025 & 2 & DC25 & 702 & 1088 & 30.419412 & 36.456264 & 30.700154 & 36.016902 \\
ERG 005 & 2 & DC05 & 1225 & 1345 & 30.558989 & 36.116371 & 30.335410 & 36.073223 \\
ERG 010 & 2 & DC10 & 1740 & 1640 & 30.955885 & 35.020271 & 30.946175 & 35.038647 \\
ERG 038 & 2 & DC38 & 1798 & 1700 & 32.099903 & 32.641815 & 32.099880 & 32.662918 \\
ERG 039 & 2 & DC39 & 1240 & 1150 & 32.099991 & 32.662758 & 32.099967 & 32.664719 \\
ERG 061 & 2 & DC61 & 1245 & 1165 & 33.524723 & 31.096963 & 33.536652 & 31.096920 \\
ERG145 & 4 & HS145 & 688 & 850 & 29.800217 & 36.404784 & 29.785855 & 36.395339 \\
\hline
\end{tabular}

601

602 Table 2: Sample characteristics and mineralogical composition.

\begin{tabular}{|c|c|c|c|c|c|c|}
\hline Samples & Subsample & Substrate & $\begin{array}{l}\text { Macroscopic } \\
\text { morphology }\end{array}$ & $\begin{array}{l}\text { Total thickness } \\
(\mathrm{mm})\end{array}$ & $\begin{array}{c}\text { Powdered } \\
\text { thickness }(\mathrm{mm})^{\mathrm{a}}\end{array}$ & Mineralogy \\
\hline DC05A & - & Phosphorite & $\begin{array}{l}\text { Nodule, Massive, } \\
\text { phosphatized }\end{array}$ & 30 & $0-30$ & $10 \AA ̊$ stable Mn-phase, CFA \\
\hline DC10C & - & Phosphorite & Laminated/botryoidal & 40 & $0-40$ & Vernadite $\left(\delta-\mathrm{MnO}_{2}\right)$ \\
\hline DC10D & - & Phosphorite & Laminated/botryoidal & 50 & $0-40$ & Vernadite $\left(\delta-\mathrm{MnO}_{2}\right)$ \\
\hline DC25A & - & Phosphorite & Massive, phosphatized & 25 & $0-25$ & $10 \AA ̊$ stable Mn-phase, CFA \\
\hline DC25C & - & Phosphorite & Laminated & 20 & $0-20$ & Vernadite $\left(\delta-\mathrm{MnO}_{2}\right)$ \\
\hline DC38A & - & Phosphorite & Laminated/botryoidal & 25 & $0-25$ & Vernadite $\left(\delta-\mathrm{MnO}_{2}\right)$ \\
\hline DC38B & - & Phosphorite & Botryoidal & 25 & $0-25$ & Vernadite $\left(\delta-\mathrm{MnO}_{2}\right)$ \\
\hline DC39B & - & Phosphorite & Botryoidal & 10 & $0-10$ & Vernadite $\left(\delta-\mathrm{MnO}_{2}\right)$ \\
\hline DC61B & - & Volcanic & Laminated & 12 & $0-12$ & Vernadite $\left(\delta-\mathrm{MnO}_{2}\right)$ \\
\hline ML39B & - & Phosphorite & Layered, phosphatized & 18 & $0-18$ & $10 \AA ̊$ stable Mn-phase, CFA \\
\hline ML64B & - & Phosphorite & Layered & 20 & $0-20$ & Vernadite $\left(\delta-\mathrm{MnO}_{2}\right)$ \\
\hline \multirow{2}{*}{ ML67B } & 2 & Older crust & Layered & \multirow{2}{*}{36} & $0-6$ & n.d. \\
\hline & 1 & - & Massive & & $6-36$ & $10 \AA ̊$ stable Mn-phase, CFA \\
\hline ML75A & - & Phosphorite & Laminated/botryoidal & 25 & $0-25$ & Vernadite $\left(\delta-\mathrm{MnO}_{2}\right)$ \\
\hline ML77A & - & Phosphorite & Laminated & 16 & $0-16$ & Vernadite $\left(\delta-\mathrm{MnO}_{2}\right)$ \\
\hline HS145 $A^{b}$ & - & Phosphorite & Botryoidal & 30 & - & n.d. \\
\hline ML11A $^{b}$ & - & Older crust & Layered & 35 & - & n.d. \\
\hline
\end{tabular}

603 a Powdered thickness is measured from the top of the sample to the bottom; ${ }^{\text {b }}$ Samples analyzed for ${ }^{87} \mathrm{Sr} /{ }^{86} \mathrm{Sr}$ ratio; n.d.:

604 not determined;

605

606 Table 3: WDS (Wavelength-Dispersive X-Ray Spectroscopy) results of EPMA of layered growth 607 structures of different reflectivity (low reflectivity $=$ dark) and (higher reflectivity = light) within sample 608 ML77A.

\begin{tabular}{|c|c|c|c|c|c|c|c|c|c|c|c|c|c|}
\hline \multirow{2}{*}{\multicolumn{7}{|c|}{ Dark Layers }} & \multicolumn{7}{|c|}{ Light Layers } \\
\hline & & $\mathrm{Ni}$ & $\mathrm{Zn}$ & Co & $\mathrm{Cu}$ & Total & $\mathrm{Mn}$ & $\mathrm{Fe}$ & $\mathrm{Ni}$ & $\mathrm{Zn}$ & Co & C & Total \\
\hline wt. $\%$ & wt.\% & wt. $\%$ & wt. \% & wt. $\%$ & wt. $\%$ & wt. $\%$ & wt.\% & wt.\% & wt.\% & wt. $\%$ & wt. $\%$ & wt. & wt. $\%$ \\
\hline 18.79 & 11.60 & 0.35 & 0.14 & 0.20 & 0.00 & 31.08 & 14.40 & 19.07 & 0.23 & 0.11 & 0.18 & 0.0 & \\
\hline
\end{tabular}




\begin{tabular}{|c|c|c|c|c|c|c|c|c|c|c|c|c|c|c|}
\hline & 17.97 & 11.81 & 0.32 & 0.05 & 0.18 & 0.00 & 30.33 & 15.38 & 18.64 & 0.23 & 0.08 & 0.17 & 0.00 & 34.50 \\
\hline & 17.24 & 12.44 & 0.24 & 0.22 & 0.04 & 0.08 & 30.25 & 16.26 & 14.87 & 0.31 & 0.16 & 0.48 & 0.09 & 32.16 \\
\hline & 16.59 & 13.20 & 0.37 & 0.20 & 0.14 & 0.06 & 30.57 & 16.16 & 14.78 & 0.19 & 0.22 & 0.40 & 0.00 & 31.75 \\
\hline & 17.52 & 13.29 & 0.22 & 0.14 & 0.13 & 0.08 & 31.38 & 16.00 & 16.42 & 0.23 & 0.27 & 0.38 & 0.00 & 33.29 \\
\hline & 15.98 & 14.30 & 0.27 & 0.10 & 0.09 & 0.08 & 30.83 & 12.97 & 17.56 & 0.15 & 0.21 & 0.35 & 0.04 & 31.28 \\
\hline & 15.52 & 14.62 & 0.26 & 0.31 & 0.14 & 0.03 & 30.89 & 15.10 & 17.34 & 0.26 & 0.01 & 0.37 & 0.01 & 33.09 \\
\hline & 16.38 & 13.78 & 0.30 & 0.07 & 0.19 & 0.00 & 30.71 & 12.26 & 17.65 & 0.18 & 0.96 & 0.36 & 0.00 & 31.40 \\
\hline & 15.63 & 13.74 & 0.28 & 0.05 & 0.24 & 0.11 & 30.06 & 19.30 & 11.90 & 0.35 & 0.13 & 0.37 & 0.03 & 32.09 \\
\hline & 17.03 & 12.55 & 0.26 & 0.00 & 0.27 & 0.06 & 30.18 & 16.47 & 13.73 & 0.25 & 0.15 & 0.41 & 0.00 & 31.01 \\
\hline & 17.46 & 11.16 & 0.30 & 0.15 & 0.20 & 0.00 & 29.27 & 16.77 & 14.36 & 0.26 & 0.17 & 0.23 & 0.00 & 31.77 \\
\hline & 16.91 & 11.39 & 0.26 & 0.08 & 0.25 & 0.00 & 28.89 & 16.15 & 16.79 & 0.23 & 0.26 & 0.31 & 0.00 & 33.74 \\
\hline & 18.58 & 11.81 & 0.28 & 0.08 & 0.20 & 0.00 & 30.95 & 15.36 & 17.93 & 0.17 & 0.16 & 0.14 & 0.00 & 33.75 \\
\hline & 18.73 & 11.71 & 0.35 & 0.06 & 0.29 & 0.00 & 31.15 & 18.24 & 12.98 & 0.25 & 0.16 & 0.42 & 0.00 & 32.05 \\
\hline & 19.33 & 11.51 & 0.32 & 0.11 & 0.33 & 0.02 & 31.62 & 17.46 & 12.54 & 0.24 & 0.17 & 0.36 & 0.01 & 30.78 \\
\hline & 18.66 & 10.85 & 0.27 & 0.14 & 0.26 & 0.00 & 30.17 & 17.86 & 12.15 & 0.23 & 0.00 & 0.51 & 0.04 & 30.78 \\
\hline & 18.18 & 11.23 & 0.27 & 0.12 & 0.27 & 0.10 & 30.16 & 14.35 & 17.22 & 0.14 & 0.21 & 0.30 & 0.09 & 32.31 \\
\hline & 18.22 & 10.50 & 0.38 & 0.15 & 0.50 & 0.00 & 29.76 & 17.74 & 12.76 & 0.24 & 0.22 & 0.51 & 0.08 & 31.56 \\
\hline & 17.72 & 10.48 & 0.32 & 0.02 & 0.39 & 0.03 & 28.97 & 18.33 & 12.24 & 0.27 & 0.11 & 0.29 & 0.01 & 31.24 \\
\hline & 17.67 & 10.56 & 0.28 & 0.07 & 0.34 & 0.00 & 28.92 & 16.71 & 12.41 & 0.35 & 0.32 & 0.41 & 0.08 & 30.27 \\
\hline & 18.26 & 11.66 & 0.33 & 0.15 & 0.45 & 0.05 & 30.89 & 17.72 & 12.74 & 0.32 & 0.33 & 0.53 & 0.06 & 31.71 \\
\hline & 18.43 & 11.41 & 0.28 & 0.15 & 0.39 & 0.05 & 30.70 & 17.96 & 12.20 & 0.34 & 0.26 & 0.33 & 0.03 & 31.12 \\
\hline & 17.01 & 10.73 & 0.28 & 0.08 & 0.54 & 0.00 & 28.64 & 17.25 & 12.64 & 0.32 & 0.61 & 0.41 & 0.00 & 31.22 \\
\hline & 18.58 & 11.01 & 0.36 & 0.22 & 0.48 & 0.07 & 30.72 & 14.98 & 16.85 & 0.21 & 0.36 & 0.31 & 0.05 & 32.77 \\
\hline & 17.79 & 10.27 & 0.33 & 0.17 & 0.46 & 0.00 & 29.01 & 17.99 & 11.39 & 0.26 & 0.25 & 0.40 & 0.00 & 30.28 \\
\hline & 17.84 & 10.94 & 0.26 & 0.13 & 0.40 & 0.10 & 29.67 & 18.60 & 13.11 & 0.26 & 0.27 & 0.43 & 0.04 & 32.71 \\
\hline & 16.98 & 10.02 & 0.29 & 0.16 & 0.30 & 0.08 & 27.83 & 17.45 & 14.39 & 0.27 & 0.33 & 0.30 & 0.03 & 32.78 \\
\hline & 18.47 & 10.90 & 0.29 & 0.27 & 0.49 & 0.04 & 30.47 & 16.31 & 14.69 & 0.20 & 0.19 & 0.27 & 0.10 & 31.76 \\
\hline & 16.58 & 12.26 & 0.29 & 0.39 & 0.49 & 0.14 & 30.14 & 19.09 & 12.24 & 0.30 & 0.19 & 0.53 & 0.00 & 32.34 \\
\hline & 15.05 & 14.18 & 0.22 & 0.30 & 0.24 & 0.00 & 29.99 & 15.45 & 17.61 & 0.21 & 0.14 & 0.36 & 0.00 & 33.77 \\
\hline & 16.48 & 14.91 & 0.22 & 0.30 & 0.29 & 0.08 & 32.28 & 15.80 & 15.54 & 0.25 & 0.06 & 0.42 & 0.00 & 32.08 \\
\hline & 16.41 & 12.49 & 0.23 & 0.34 & 0.33 & 0.00 & 29.80 & 18.59 & 13.24 & 0.29 & 0.27 & 0.52 & 0.03 & 32.94 \\
\hline & 15.02 & 12.02 & 0.24 & 0.49 & 0.44 & 0.05 & 28.27 & 15.40 & 17.94 & 0.24 & 0.19 & 0.16 & 0.07 & 34.00 \\
\hline Average & 17.36 & 11.98 & 0.29 & 0.16 & 0.30 & 0.04 & 30.14 & 16.54 & 14.78 & 0.25 & 0.23 & 0.36 & 0.03 & 32.19 \\
\hline
\end{tabular}

609

610

611 Table 4: Foraminifera used for biostratigraphy of phosphorite samples.

\begin{tabular}{|c|c|c|c|}
\hline Foraminifera & $\begin{array}{l}\text { First } \\
\text { Occurence }\end{array}$ & $\begin{array}{l}\text { Last } \\
\text { Occurence }\end{array}$ & Reference \\
\hline Nummulites sp. & $\begin{array}{l}\text { Middle } \\
\text { Paleocene }\end{array}$ & Oligocene & $\begin{array}{l}\text { Loeblich \& Tappan (1987), BouDagher- } \\
\text { Fadel (2008) }\end{array}$ \\
\hline Discocyclina $s p$. & $\begin{array}{l}\text { Middle } \\
\text { Paleocene }\end{array}$ & $\begin{array}{l}\text { Upper } \\
\text { Eocene }\end{array}$ & $\begin{array}{l}\text { Loeblich \& Tappan (1987), BouDagher- } \\
\text { Fadel (2008) }\end{array}$ \\
\hline Morozovella sp. & Paleocene & $\begin{array}{l}\text { Middle } \\
\text { Eocene }\end{array}$ & Blow (1979) \\
\hline Orbulina sp. & $\begin{array}{l}\text { Middle Miocene } \\
(15.1 \mathrm{Ma})\end{array}$ & $\begin{array}{l}\text { living } \\
\text { species }\end{array}$ & Kennett \& Srinivasan (1983) \\
\hline
\end{tabular}

612

613 Table 5: Electron probe microanalyses (WDS) in samples ML77A, DC38A, DC25A and DC61B. Points

614 of analyses are shown in figures 4 and 5.

\begin{tabular}{lrrrrr}
\hline Sample & ML77A & ML77A & DC38A & DC25A & DC61B \\
\hline Spot & EPMA1 & EPMA2 & EPMA3 & EPMA4 & EPMA5 \\
\hline Fe (\%) & 10.63 & 0.03 & 1.34 & 5.39 & 12.83 \\
$\mathrm{Mn}$ & 0.12 & 0.02 & 0.06 & 4.07 & 0.23 \\
$\mathrm{P}$ & 11.43 & 0.06 & 8.51 & 8.03 & 2.05 \\
$\mathrm{Ca}$ & 25.74 & 36.37 & 29.95 & 28.17 & 6.05 \\
$\mathrm{Na}$ & 0.87 & 0.04 & 0.71 & 0.67 & 0.19 \\
$\mathrm{Mg}$ & 0.55 & 0.58 & 0.56 & 0.66 & 1.79 \\
$\mathrm{~F}$ & 4.84 & 0.00 & 4.82 & 4.75 & 0.41 \\
$\mathrm{Al}$ & 0.44 & 0.10 & 1.71 & 0.53 & 5.97 \\
$\mathrm{Si}$ & 0.29 & 0.18 & 3.92 & 0.26 & 12.13 \\
$\mathrm{~K}$ & 0.02 & 0.05 & 0.71 & 0.07 & 2.47 \\
$\mathrm{Si}$ & 1.07 & 1.07 & 0.00 & 0.03 & 0.01 \\
$\mathrm{Ti}$ & 0.00 & 0.00 & 0.17 & 0.00 & 2.37 \\
$\mathrm{Cr}$ & 0.00 & 0.00 & 0.00 & 0.03 & 0.06 \\
$\mathrm{Co}$ & 0.00 & 0.02 & 0.02 & 0.03 & 0.00 \\
$\mathrm{Cu}$ & 0.00 & 0.01 & 0.06 & 0.00 & 0.00
\end{tabular}


615

\begin{tabular}{llllll}
$\mathrm{Ni}$ & 0.02 & 0.00 & 0.02 & 0.04 & 0.02 \\
$\mathrm{Ba}$ & 0.05 & 0.01 & 0.04 & 0.00 & 0.24 \\
\hline
\end{tabular}

616

617 Table 6: Bulk composition of ferromanganese crusts from the Rio Grande Rise.

\begin{tabular}{|c|c|c|c|c|c|c|c|c|}
\hline \multicolumn{9}{|c|}{ Non-phosphatized samples } \\
\hline & ML64B & ML67B-2 & ML75A & ML77A & DC10C & DC10D & DC25C & DC38A \\
\hline $\mathrm{Fe} \%$ & 18.35 & 17.32 & 19.03 & 18.73 & 21.28 & 21.32 & 15.76 & 19.16 \\
\hline $\mathrm{Mn}$ & 25.87 & 24.11 & 24.30 & 25.04 & 23.49 & 23.05 & 21.04 & 23.74 \\
\hline $\mathrm{Mn} / \mathrm{Fe}$ & 1.41 & 1.39 & 1.28 & 1.34 & 1.10 & 1.08 & 1.34 & 1.24 \\
\hline $\mathrm{Ca}$ & 3.46 & 2.66 & 2.76 & 2.74 & 2.57 & 2.54 & 8.43 & 2.62 \\
\hline $\mathrm{Na}$ & 1.53 & 1.32 & 1.56 & 1.53 & 1.52 & 1.46 & 1.15 & 1.55 \\
\hline $\mathrm{Mg}$ & 1.37 & 1.27 & 1.25 & 1.22 & 1.27 & 1.30 & 1.60 & 1.21 \\
\hline $\mathrm{Al}$ & 0.54 & 0.60 & 0.51 & 0.46 & 0.88 & 1.15 & 0.41 & 0.84 \\
\hline $\mathrm{K}$ & 0.36 & 0.30 & 0.33 & 0.33 & 0.35 & 0.46 & 0.23 & 0.38 \\
\hline $\mathrm{P}$ & 0.48 & 0.49 & 0.51 & 0.46 & 0.50 & 0.47 & 0.40 & 0.49 \\
\hline Co mg/kg & 9208 & 7615 & 9795 & 10484 & 7734 & 7502 & 6554 & 8439 \\
\hline $\mathrm{Ni}$ & 4740 & 4848 & 3715 & 3823 & 3416 & 3607 & 4216 & 3734 \\
\hline $\mathrm{Cu}$ & 387 & 467 & 323 & 366 & 398 & 549 & 323 & 378 \\
\hline $\mathrm{Zn}$ & 566 & 559 & 535 & 571 & 602 & 652 & 439 & 573 \\
\hline V & 1093 & 1020 & 1057 & 1038 & 1069 & 1110 & 960 & 1003 \\
\hline Mo & 716 & 649 & 633 & 658 & 641 & 642 & 514 & 655 \\
\hline $\mathrm{Li}$ & 6.12 & 3.06 & 3.33 & 2.43 & 3.38 & 7.97 & 2.29 & 5.01 \\
\hline $\mathrm{Sc}$ & 4.42 & 4.68 & 5.46 & 5.63 & 9.74 & 8.27 & 4.49 & 6.42 \\
\hline $\mathrm{Ti}$ & 9884 & 10495 & 11251 & 11564 & 10599 & 10789 & 8758 & 10578 \\
\hline $\mathrm{Rb}$ & 3.20 & 1.97 & 2.76 & 2.85 & 3.67 & 7.49 & 3.06 & 4.59 \\
\hline $\mathrm{Sr}$ & 2039 & 1907 & 1967 & 1971 & 1881 & 1849 & 2162 & 1829 \\
\hline Y & 150 & 179 & 191 & 162 & 206 & 146 & 166 & 154 \\
\hline $\mathrm{Zr}$ & 367 & 418 & 407 & 450 & 494 & 530 & 271 & 460 \\
\hline $\mathrm{Nb}$ & 75 & 72 & 85 & 88 & 73 & 89 & 81 & 73 \\
\hline Mo & 653 & 631 & 624 & 651 & 578 & 541 & 511 & 629 \\
\hline $\mathrm{Te}$ & 86.69 & 90.72 & 88.93 & 95.63 & 60.50 & 69.13 & 91.82 & 72.25 \\
\hline $\mathrm{Ba}$ & 1324 & 1359 & 1311 & 1447 & 1338 & 1575 & 1258 & 1394 \\
\hline $\mathrm{La}$ & 253.92 & 254.13 & 301.60 & 298.90 & 313.42 & 288.44 & 249.38 & 275.26 \\
\hline $\mathrm{Ce}$ & 1560.27 & 1663.15 & 1629.58 & 1929.88 & 1586.37 & 1928.73 & 1425.92 & 1864.80 \\
\hline $\operatorname{Pr}$ & 51.37 & 51.22 & 60.15 & 59.36 & 63.29 & 59.88 & 54.56 & 55.50 \\
\hline $\mathrm{Nd}$ & 205.40 & 208.61 & 246.14 & 236.89 & 261.90 & 241.79 & 223.46 & 223.85 \\
\hline $\mathrm{Sm}$ & 42.56 & 42.39 & 49.78 & 47.99 & 53.06 & 49.00 & 46.27 & 45.57 \\
\hline $\mathrm{Eu}$ & 9.85 & 9.94 & 11.61 & 10.99 & 12.78 & 11.52 & 10.65 & 10.53 \\
\hline Gd & 43.02 & 43.63 & 51.56 & 47.58 & 58.24 & 48.89 & 46.59 & 46.19 \\
\hline $\mathrm{Tb}$ & 6.57 & 6.74 & 7.79 & 7.36 & 8.81 & 7.62 & 7.12 & 7.14 \\
\hline Dy & 39.80 & 41.26 & 47.53 & 45.05 & 54.70 & 45.15 & 42.53 & 42.43 \\
\hline Но & 8.09 & 8.73 & 9.78 & 9.17 & 11.13 & 9.01 & 8.55 & 8.63 \\
\hline $\mathrm{Er}$ & 23.58 & 25.42 & 28.72 & 26.46 & 32.01 & 24.94 & 24.44 & 24.35 \\
\hline $\mathrm{Tm}$ & 3.40 & 3.72 & 4.08 & 3.82 & 4.45 & 3.56 & 3.42 & 3.54 \\
\hline $\mathrm{Yb}$ & 20.97 & 23.56 & 25.25 & 23.61 & 28.67 & 22.30 & 20.73 & 22.30 \\
\hline $\mathrm{Lu}$ & 3.09 & 3.63 & 3.79 & 3.44 & 4.27 & 3.27 & 3.08 & 3.32 \\
\hline $\mathrm{Hf}$ & 6.68 & 6.99 & 6.85 & 8.28 & 9.46 & 12.26 & 4.82 & 8.51 \\
\hline Тa & 1.19 & 1.40 & 1.38 & 1.51 & 1.33 & 1.70 & 1.28 & 1.34 \\
\hline W & 145 & 128 & 143 & 156 & 130 & 123 & 122 & 136 \\
\hline $\mathrm{Pb}$ & 2202 & 2363 & 2407 & 2411 & 2110 & 1981 & 1945 & 2204 \\
\hline Th & 29.73 & 26.42 & 31.73 & 39.53 & 26.25 & 40.57 & 25.20 & 37.54 \\
\hline $\mathrm{U}$ & 12.52 & 13.21 & 13.67 & 12.97 & 12.91 & 11.86 & 11.98 & 12.24 \\
\hline Y/Ho & 18.48 & 20.51 & 19.53 & 17.68 & 18.52 & 16.23 & 19.37 & 17.80 \\
\hline $\mathrm{Zr} / \mathrm{Hf}$ & 54.87 & 59.76 & 59.38 & 54.31 & 52.27 & 43.20 & 56.33 & 53.98 \\
\hline $\mathrm{Nb} / \mathrm{Ta}$ & 63.05 & 51.67 & 61.69 & 57.99 & 54.50 & 52.61 & 62.75 & 54.62 \\
\hline $\mathrm{Ce}_{\mathrm{SN}} / \mathrm{Ce}_{\mathrm{SN}} *^{1}$ & 3.14 & 3.35 & 2.78 & 3.33 & 2.59 & 3.38 & 2.81 & 3.47 \\
\hline $\mathrm{Y}_{\mathrm{SN}} / \mathrm{Y}_{\mathrm{SN}} *^{2}$ & 0.66 & 0.75 & 0.71 & 0.64 & 0.67 & 0.58 & 0.69 & 0.64 \\
\hline$\Sigma$ REE & 2272 & 2386 & 2477 & 2751 & 2493 & 2744 & 2167 & 2633 \\
\hline G.R. $(\mathrm{mm} / \mathrm{Ma})^{3}$ & 1.88 & 2.45 & 1.73 & 1.58 & 2.40 & 2.51 & 3.08 & 2.12 \\
\hline Thickness (mm) & 20 & 6 & 25 & 16 & 40 & 40 & 20 & 25 \\
\hline Age $(\mathrm{Ma})$ & 10.6 & 2.4 & 14.4 & 10.1 & 16.7 & 15.9 & 6.5 & 11.8 \\
\hline
\end{tabular}

618 SN: Shale normalized. $\mathrm{Ce}_{\mathrm{SN}} / \mathrm{Ce}_{\mathrm{SN}}{ }^{*}=\mathrm{Ce}_{\mathrm{SN}} /\left(0.5 \mathrm{La}_{\mathrm{SN}}+0.5 \mathrm{Pr}_{\mathrm{SN}}\right)$

$619{ }^{2} \mathrm{SN}$ : Shale normalized. $\mathrm{Y}_{\mathrm{SN}} / \mathrm{Y}_{\mathrm{SN}}{ }^{*}=\mathrm{Y}_{\mathrm{SN}} /\left(0.5 \mathrm{Dy}_{\mathrm{SN}}+0.5 \mathrm{Ho}_{\mathrm{SN}}\right)$

$620{ }^{3}$ G.R. is the growth rate calculated as G.R. $=1,28 /[\mathrm{Co}(\%)-0,24]$ (Puteanus \& Halbach, 1988) 
Table 6: continued.

\begin{tabular}{|c|c|c|c|c|c|c|c|}
\hline & \multicolumn{3}{|c|}{ Non-phosphatized samples } & \multicolumn{4}{|c|}{ Phosphatized samples } \\
\hline & DC38B & DC39B & DC61B & ML39B & ML67B-1 & DC05A & DC25A \\
\hline $\mathrm{Fe} \%$ & 19.91 & 20.18 & 17.88 & 12.71 & 6.61 & 9.14 & 7.96 \\
\hline $\mathrm{Mn}$ & 20.87 & 22.97 & 25.12 & 19.00 & 16.09 & 15.62 & 10.06 \\
\hline $\mathrm{Mn} / \mathrm{Fe}$ & 1.05 & 1.14 & 1.41 & 1.49 & 2.43 & 1.71 & 1.26 \\
\hline $\mathrm{Ca}$ & 2.78 & 2.77 & 2.83 & 11.93 & 18.08 & 11.54 & 20.67 \\
\hline $\mathrm{Na}$ & 1.66 & 1.63 & 2.08 & 1.01 & 0.93 & 0.94 & 0.81 \\
\hline $\mathrm{Mg}$ & 1.31 & 1.20 & 1.41 & 1.85 & 1.97 & 1.94 & 1.94 \\
\hline $\mathrm{Al}$ & 1.11 & 0.59 & 0.71 & 1.06 & 1.24 & 1.70 & 1.57 \\
\hline K & 0.36 & 0.34 & 0.34 & 0.26 & 0.27 & 0.39 & 0.23 \\
\hline $\mathrm{P}$ & 0.49 & 0.56 & 0.45 & 1.50 & 4.70 & 2.70 & 5.21 \\
\hline Co mg/kg & 9718 & 9383 & 10101 & 4234 & 2864 & 5224 & 2069 \\
\hline $\mathrm{Ni}$ & 2999 & 3501 & 3916 & 5825 & 6878 & 5391 & 4341 \\
\hline $\mathrm{Cu}$ & 441 & 421 & 286 & 375 & 306 & 716 & 395 \\
\hline $\mathrm{Zn}$ & 540 & 562 & 546 & 508 & 859 & 596 & 534 \\
\hline V & 877 & 1055 & 900 & 914 & 502 & 574 & 467 \\
\hline Mo & 517 & 601 & 670 & 455 & 314 & 391 & 247 \\
\hline $\mathrm{Li}$ & 3.62 & 2.12 & 2.50 & 37.45 & 93.73 & 78.01 & 66.42 \\
\hline $\mathrm{Sc}$ & 17.23 & 6.11 & 8.74 & 4.35 & 6.20 & 6.23 & 7.41 \\
\hline $\mathrm{Ti}$ & 11591 & 12382 & 10328 & 7464 & 3815 & 5664 & 4083 \\
\hline $\mathrm{Rb}$ & 5.26 & 3.90 & 2.43 & 3.20 & 5.11 & 9.95 & 6.14 \\
\hline $\mathrm{Sr}$ & 1722 & 1966 & 1860 & 1554 & 1727 & 1127 & 1332 \\
\hline $\mathrm{Y}$ & 210 & 201 & 197 & 164 & 234 & 201 & 195 \\
\hline $\mathrm{Zr}$ & 526 & 483 & 466 & 264 & 172 & 242 & 191 \\
\hline $\mathrm{Nb}$ & 86 & 108 & 66 & 58 & 29 & 44 & 33 \\
\hline Мo & 487 & 598 & 638 & 423 & 290 & 384 & 217 \\
\hline $\mathrm{Te}$ & 76.26 & 92.10 & 72.30 & 65.52 & 30.45 & 42.03 & 24.42 \\
\hline $\mathrm{Ba}$ & 1145 & 1338 & 1061 & 1200 & 901 & 782 & 571 \\
\hline $\mathrm{La}$ & 346.17 & 292.91 & 321.14 & 178.55 & 165.53 & 137.24 & 107.72 \\
\hline $\mathrm{Ce}$ & 1837.02 & 1904.66 & 1465.55 & 1058.96 & 525.95 & 641.25 & 349.56 \\
\hline $\operatorname{Pr}$ & 73.69 & 56.80 & 64.43 & 36.20 & 29.47 & 24.73 & 20.39 \\
\hline $\mathrm{Nd}$ & 298.30 & 232.72 & 260.41 & 147.73 & 126.07 & 104.02 & 87.59 \\
\hline $\mathrm{Sm}$ & 60.78 & 47.26 & 52.00 & 31.01 & 25.53 & 21.14 & 18.16 \\
\hline $\mathrm{Eu}$ & 14.51 & 11.05 & 12.34 & 7.35 & 6.21 & 5.13 & 4.46 \\
\hline $\mathrm{Gd}$ & 62.69 & 49.46 & 54.79 & 33.22 & 30.77 & 25.22 & 21.97 \\
\hline $\mathrm{Tb}$ & 9.74 & 7.65 & 8.35 & 5.00 & 4.44 & 3.82 & 3.28 \\
\hline Dy & 57.53 & 47.12 & 51.56 & 30.55 & 29.60 & 25.09 & 21.87 \\
\hline Ho & 11.56 & 9.83 & 10.62 & 6.61 & 6.54 & 5.64 & 5.09 \\
\hline $\mathrm{Er}$ & 32.02 & 28.87 & 30.50 & 18.86 & 19.48 & 17.76 & 15.59 \\
\hline $\mathrm{Tm}$ & 4.55 & 4.12 & 4.31 & 2.69 & 2.63 & 2.55 & 2.29 \\
\hline $\mathrm{Yb}$ & 28.47 & 26.64 & 27.73 & 16.46 & 16.36 & 16.12 & 14.40 \\
\hline $\mathrm{Lu}$ & 4.24 & 4.02 & 4.17 & 2.49 & 2.49 & 2.52 & 2.31 \\
\hline $\mathrm{Hf}$ & 10.85 & 9.57 & 6.87 & 4.87 & 3.13 & 4.47 & 3.56 \\
\hline $\mathrm{Ta}$ & 1.89 & 1.56 & 1.13 & 1.09 & 0.50 & 0.75 & 0.53 \\
\hline W & 115 & 134 & 130 & 110 & 63 & 96 & 46 \\
\hline $\mathrm{Pb}$ & 1782 & 2512 & 2221 & 1612 & 844 & 1067 & 547 \\
\hline $\mathrm{Th}$ & 47.61 & 37.10 & 28.69 & 17.85 & 9.19 & 13.75 & 8.95 \\
\hline $\mathrm{U}$ & 11.31 & 14.20 & 12.32 & 10.59 & 9.22 & 10.03 & 9.89 \\
\hline Y/Ho & 18.12 & 20.43 & 18.58 & 24.84 & 35.76 & 35.55 & 38.38 \\
\hline $\mathrm{Zr} / \mathrm{Hf}$ & 48.51 & 50.44 & 67.91 & 54.15 & 55.05 & 54.11 & 53.62 \\
\hline $\mathrm{Nb} / \mathrm{Ta}$ & 45.40 & 68.85 & 58.47 & 53.21 & 58.05 & 58.91 & 63.36 \\
\hline $\mathrm{Ce}_{\mathrm{SN}} / \mathrm{Ce}_{\mathrm{SN}} * 1$ & 2.65 & 3.39 & 2.34 & 3.03 & 1.72 & 2.52 & 1.71 \\
\hline $\mathrm{Y}_{\mathrm{SN}} / \mathrm{Y}_{\mathrm{SN}} *^{2}$ & 0.65 & 0.74 & 0.67 & 0.92 & 1.34 & 1.34 & 1.48 \\
\hline$\Sigma \mathrm{REE}$ & 2841 & 2723 & 2368 & 1576 & 991 & 1032 & 675 \\
\hline G.R. $(\mathrm{mm} / \mathrm{Ma})^{3}$ & 1.75 & 1.83 & 1.66 & - & - & - & - \\
\hline Thickness (mm) & 25 & 10 & 12 & - & - & - & - \\
\hline Age (Ma) & 14.3 & 5.5 & 7.2 & - & - & - & - \\
\hline
\end{tabular}

$1_{\mathrm{SN}}$ : Shale normalized (Post-Archean Australian Shale, PAAS, of McLennan, 1989). $\mathrm{Ce}_{\mathrm{SN}} / \mathrm{Ce}_{\mathrm{SN}}{ }^{*}=\mathrm{Ce}_{\mathrm{SN}} /\left(0.5 \mathrm{La}_{\mathrm{SN}}+0.5 \mathrm{Pr}_{\mathrm{SN}}\right)$

6272 SN: Shale normalized (Post-Archean Australian Shale, PAAS, of McLennan, 1989). $\mathrm{Y}_{\mathrm{SN}} / \mathrm{Y}_{\mathrm{SN}}{ }^{*}=\mathrm{Y}_{\mathrm{SN}} /\left(0.5 \mathrm{Dy}_{\mathrm{SN}}+0.5 \mathrm{Ho} \mathrm{SN}\right)$

$628{ }^{3}$ G.R. is the growth rate calculated as G.R.=1,28/[Co(\%)-0,24] (Puteanus \& Halbach, 1988) 
629

Table 7: ${ }^{87} \mathrm{Sr} /{ }^{86} \mathrm{Sr}$ results.

\begin{tabular}{ccc}
\hline Sample & $\begin{array}{c}{ }^{87} \mathrm{Sr} /{ }^{86} \mathrm{Sr} \\
\pm 2 \mathrm{SE}\end{array}$ & $\begin{array}{c}\text { Age } \\
(\mathrm{Ma})\end{array}$ \\
\hline ML11D & $0.70860 \pm 2$ & 17.6 \\
HS145A & $0.70880 \pm 2$ & 14.6 \\
\hline
\end{tabular}

630

631

632

633

634

635

636

637

638

639

640

641

642

643

644

645

646

647 
649

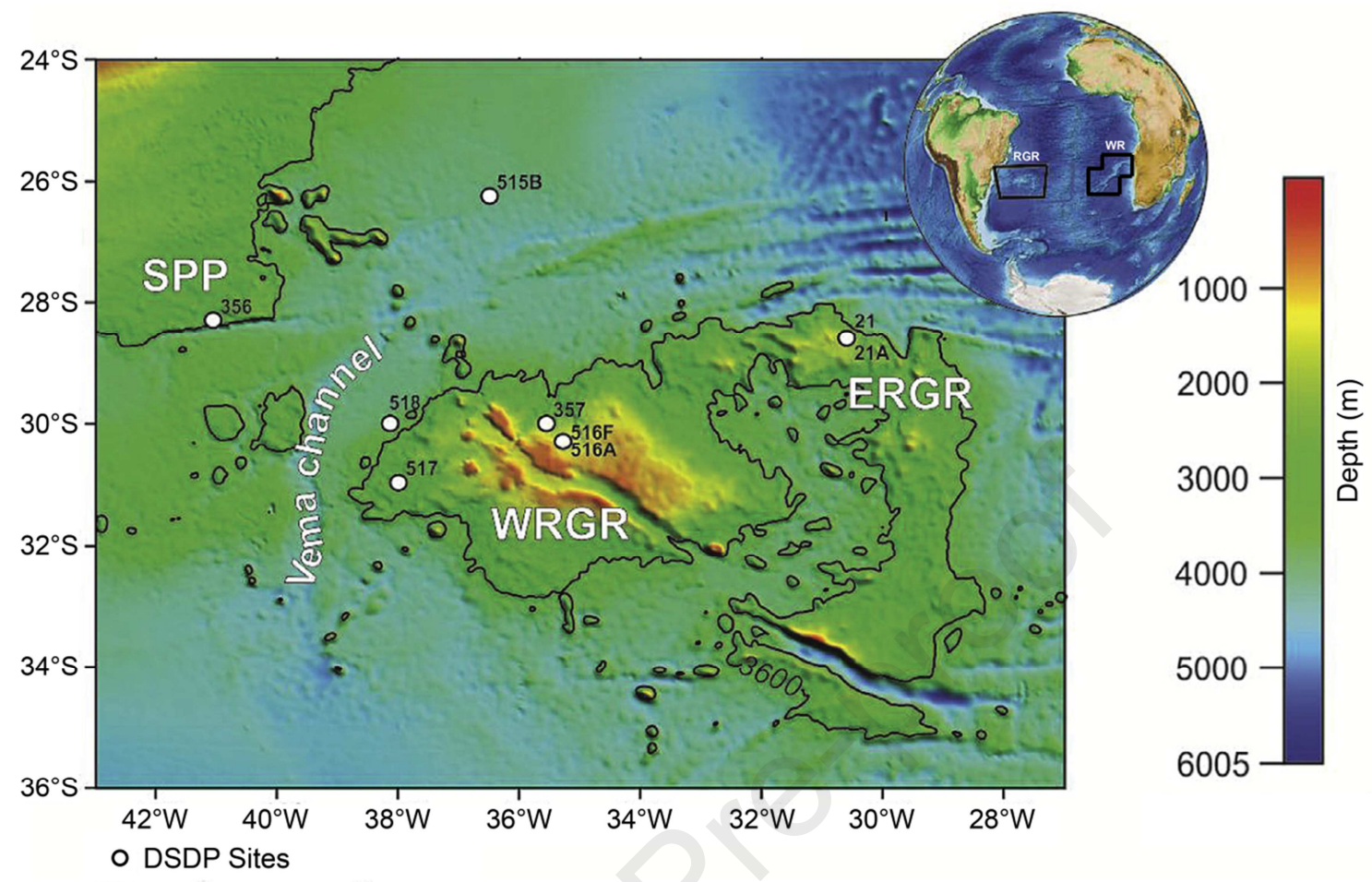

651 Fig. 1: Bathymetry from ETOPO1 showing West and East Rio Grande Rises (WRGR and ERGR), the

652 Vema channel and the São Paulo Plateau (SPP). White circles are DSDP (Deep Sea Drilling Project) Sites

653 (Constantino et al., 2017). In the globe figure, the position of Walvis Ridge (WR) and Rio Grande Rise 654 (RGR) are shown.

655 


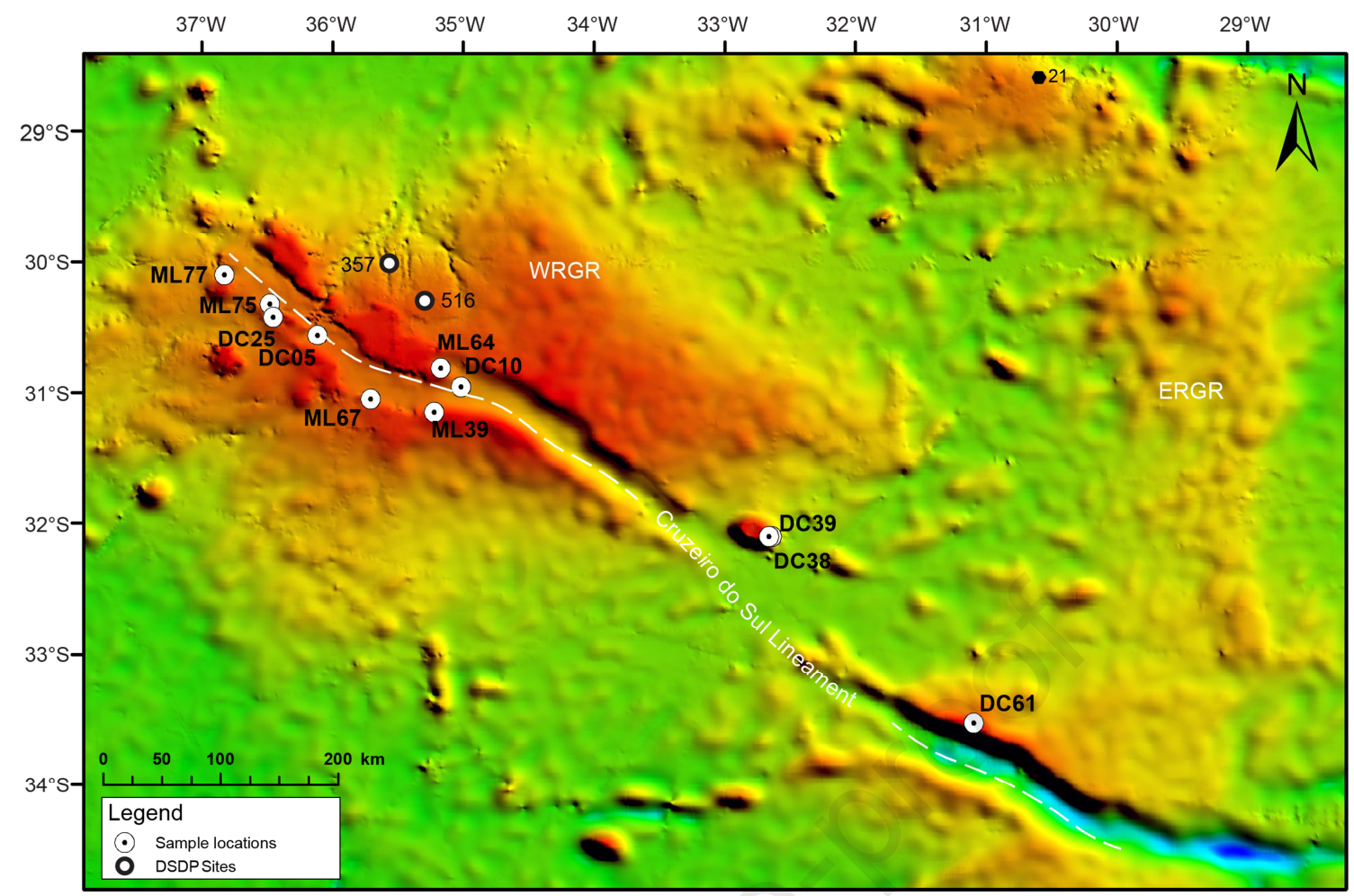

657 Fig. 2: Sample locations in the Rio Grande Rise. Deep Sea Drilling Project sites 357 and 516 are shown 658 in the map. 

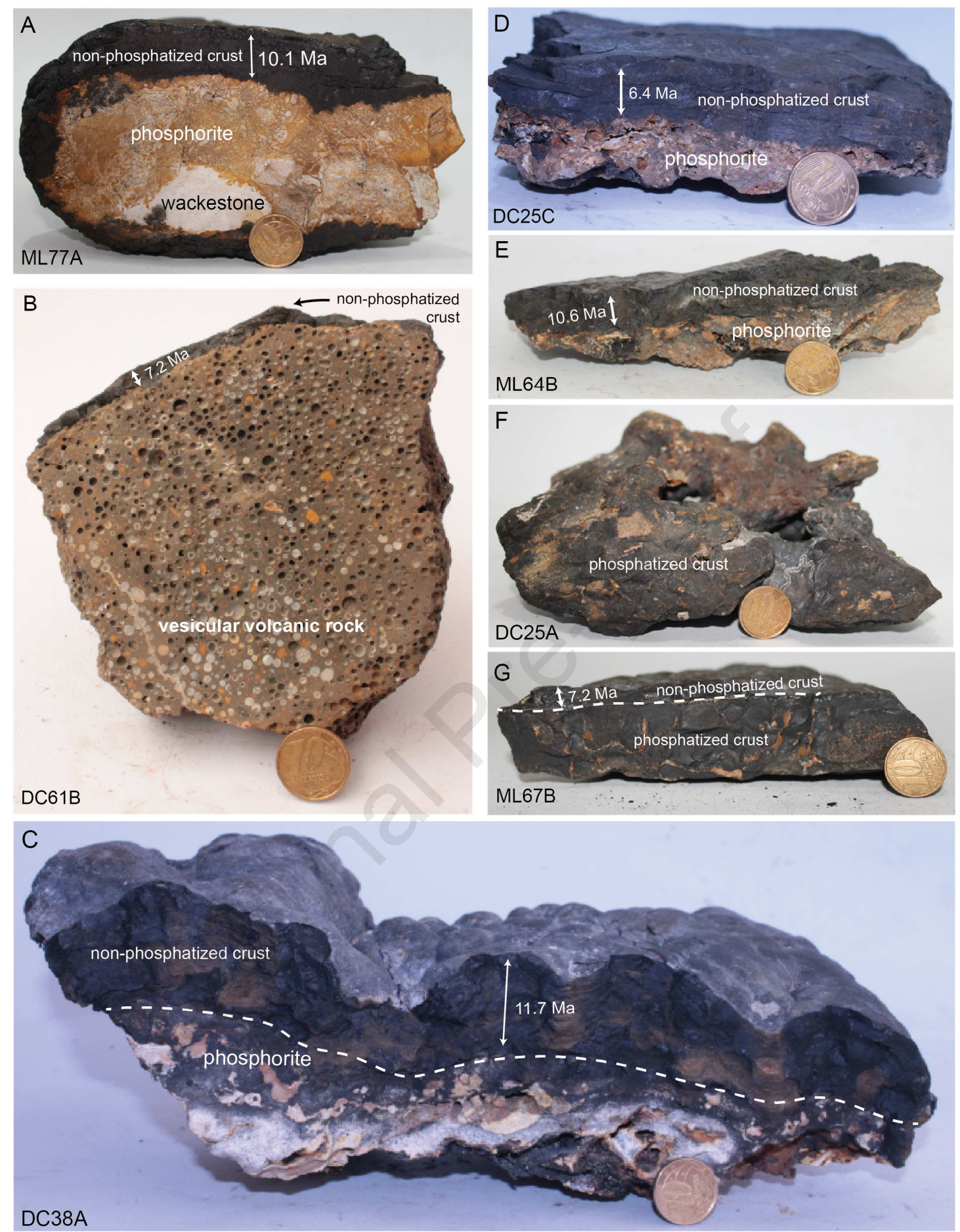

660 Fig. 3: Ferromanganese crust samples from the Cruzeiro do Sul Lineament. Ages shown are minimum 661 estimates based on Co chronology calculations. Coin diameter $=2 \mathrm{~cm}$. A. Sample ML77A. Laminated 662 Fe-Mn crust developed above phosphorite; B. Sample DC61B. Thin Fe-Mn crust above volcanic substrate; C. Sample DC38A. Botryoidal Fe-Mn crust developed above phosphorite. White dashed line indicates the boundary between the pristine crust and the phosphorite substrate impregnated with oxyhydroxides; D. Sample DC25C. Laminated Fe-Mn crust developed above phosphorite; E. Sample ML64B. Laminated crust above phosphorite; F. Sample DC25A. Irregular shaped sample composed of

667 Fe-Mn precipitates in between phosphorites; G. Sample ML67B. 6 mm-thick pristine crust developed 
668 above older phosphatized crust. White dashed line indicates the boundary between the old and the new 669 crust generations.

670
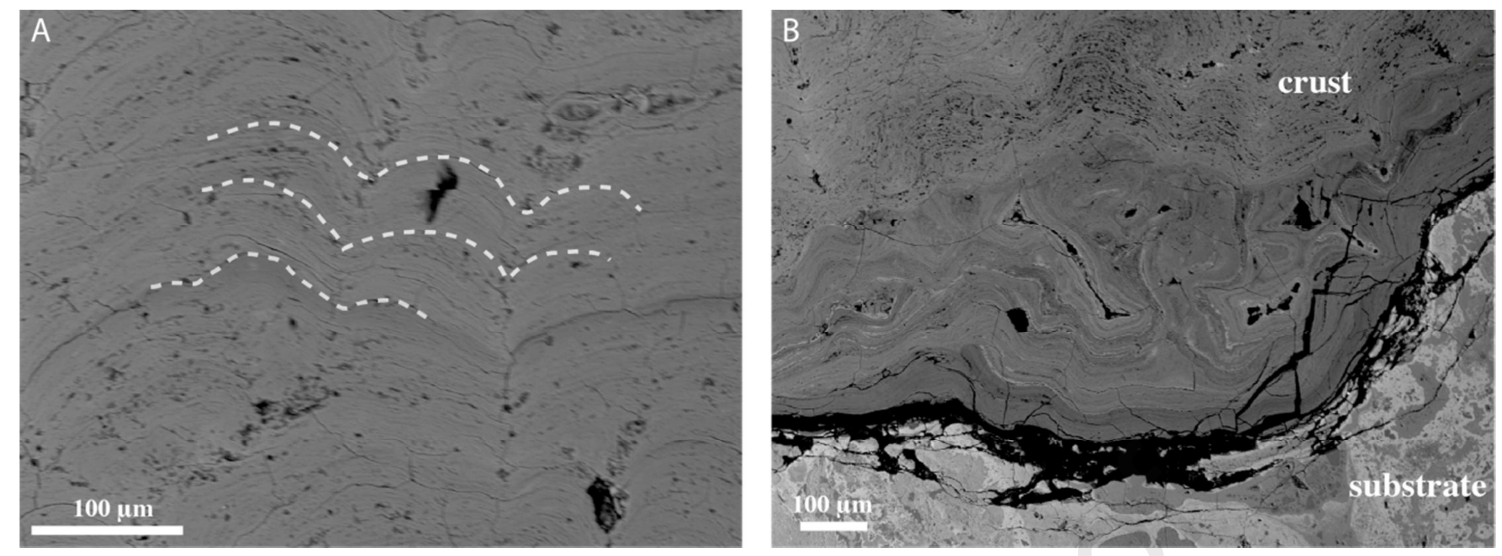

672 Fig. 4: Backscattered electrons images of sample ML77A. Layers of higher reflectance present a higher

673 concentration of metals. A. Concave growth structures are shown; B. Contact between the crust and its 674 substrate.

675 

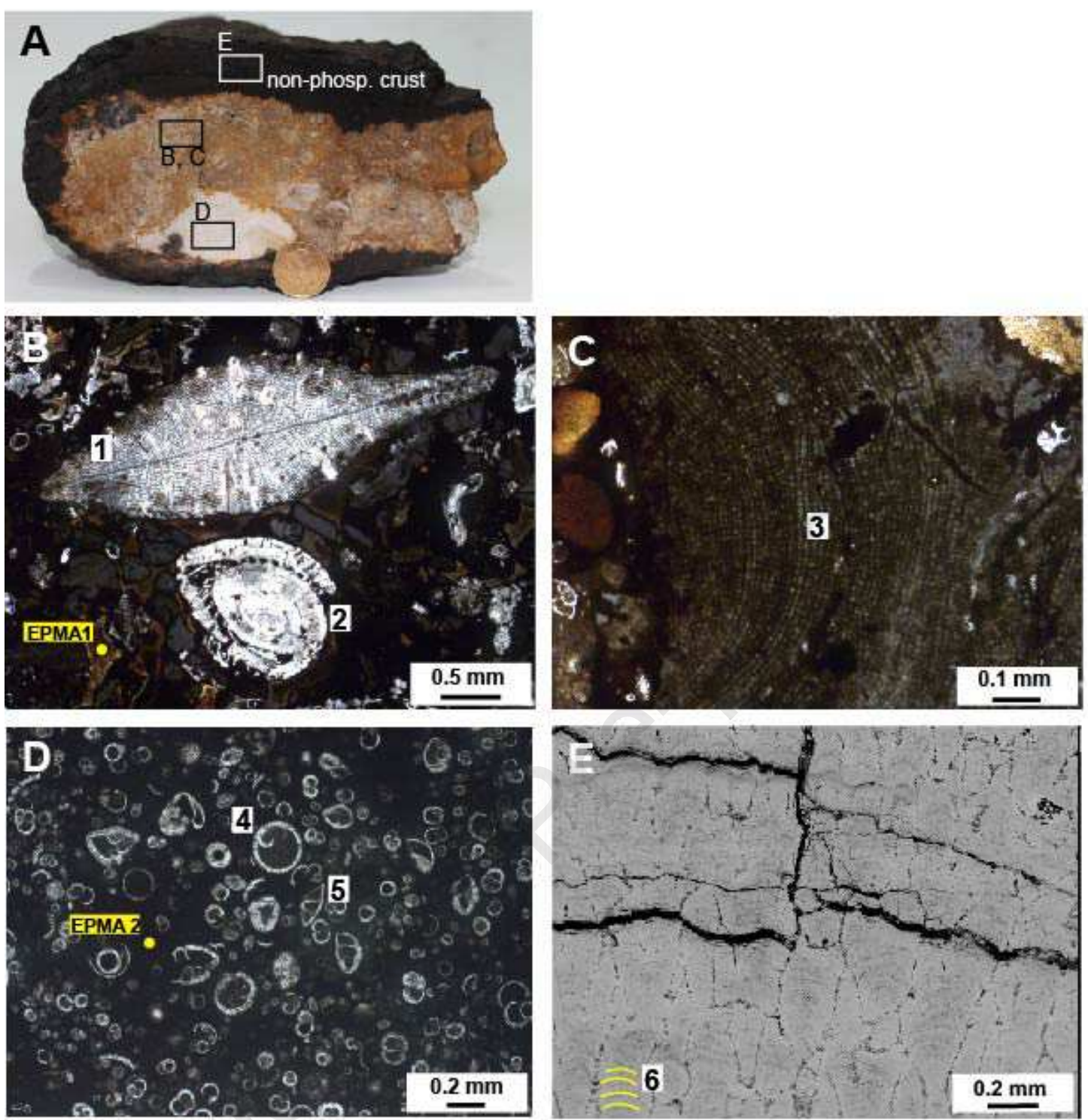

Fig. 5: A. Sample ML77A. Ferromanganese crust developed above sedimentary rock composed of an Eocene phosphatized packstone (B and C) attached to a Miocene wackestone (D) fragment; B. Photomicrography of Eocene fragment showing Discocyclina sp. (1) and Nummulites sp. (2) in a

680 carbonate fluorapatite matrix; C. Photomicrography of calcareous structure of Eocene coralline algae (3);

681 D. Photomicrography of Miocene fragment composed of planktic foraminifera in a micritic matrix.

682 Orbulina sp. (4) and Globorotalia sp. (5) are shown; E. Backscattered electron image of the

683 ferromanganese crust showing layers of different reflectance and concave growth structures (6). Yellow

684 dots are EPMA spot analyses shown in table 4 . Coin diameter $=2 \mathrm{~cm}$.

685

686

687 

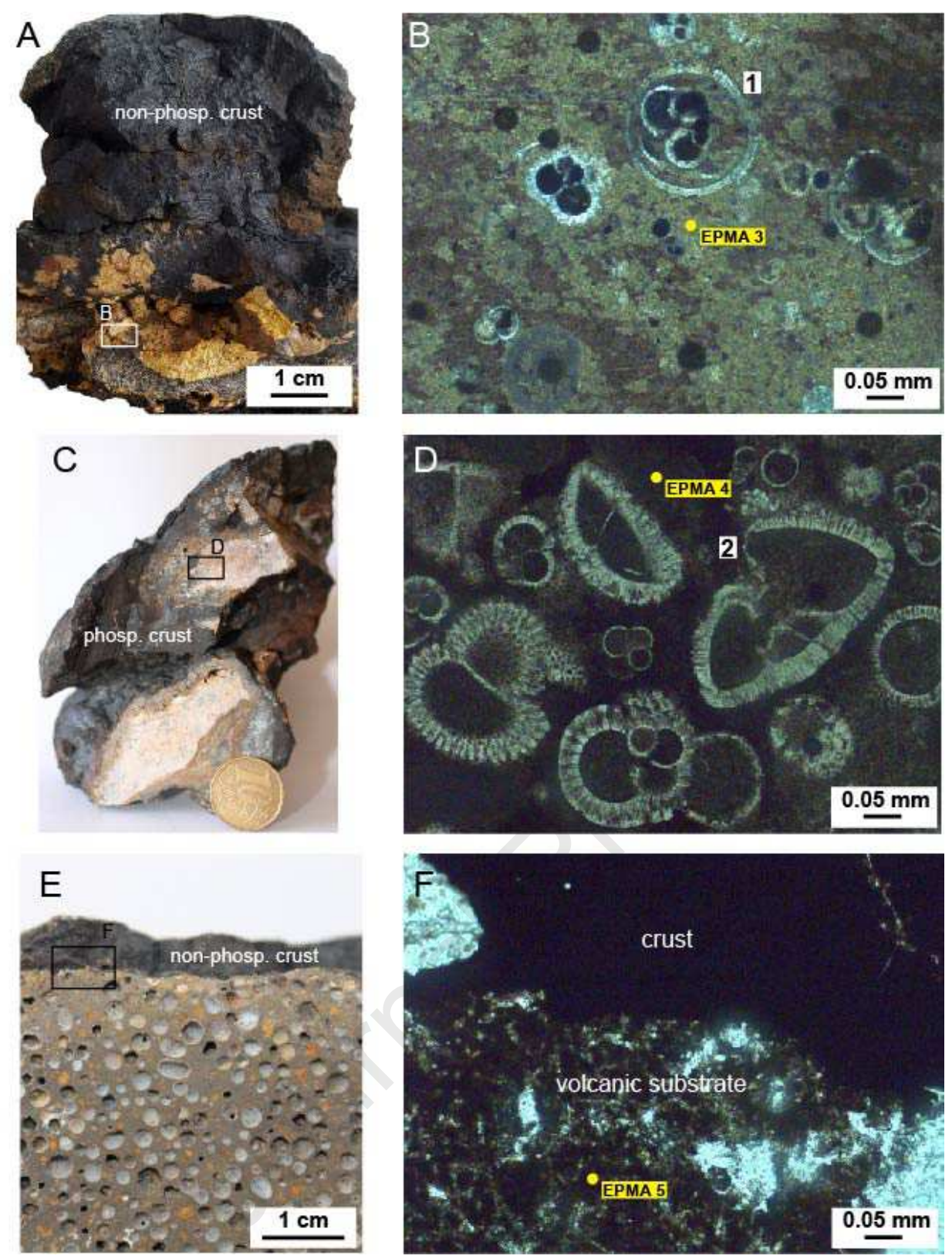

Fig. 6: A. Sample DC38A; B. Photomicrography of crust substrate in sample DC38A showing Orbulina

690 universa (1) in a carbonate fluorapatite matrix; C. Sample DC25A; D. Photomicrography of the substrate 691 in sample DC25A showing Morozovella sp. in a carbonate fluorapatite matrix; E. Sample DC61B; F.

692 Photomicrography of sample DC61B showing the contact between the volcanic substrate and the

693 overlying ferromanganese crust. Yellow dots are EPMA spot analyses shown in table 4. Coin diameter = $6942 \mathrm{~cm}$ 


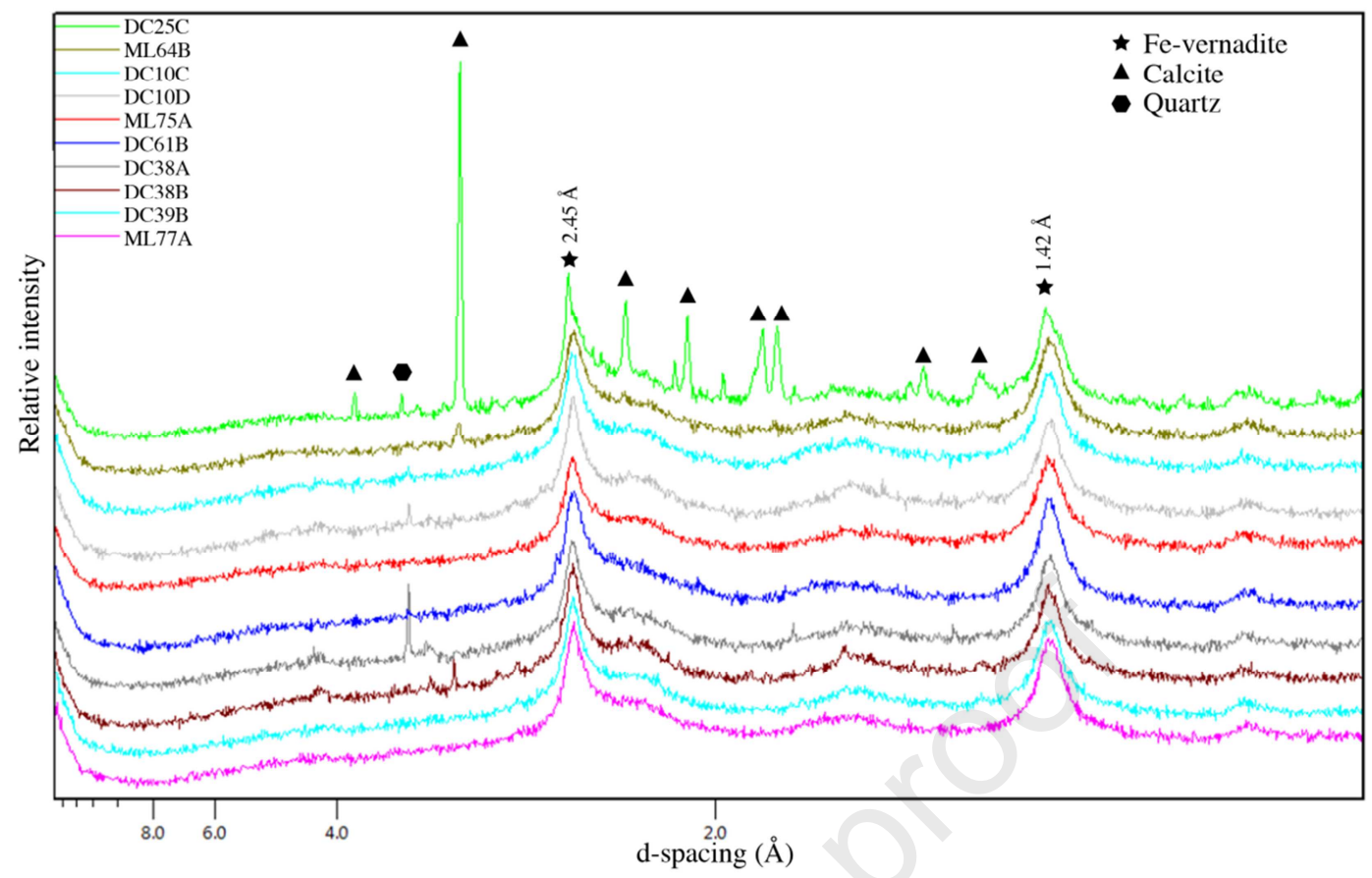

698 Fig. 7: XRD patterns of non-phosphatized crust samples. 2.45 and $1.42 \AA$ peaks characterize the Fe699 vernadite $\left(\delta-\mathrm{MnO}_{2}\right)$. Calcite is present in samples DC25C, ML64B and DC38B; quartz is present in samples DC25C, DC10C, DC10D and DC38A.

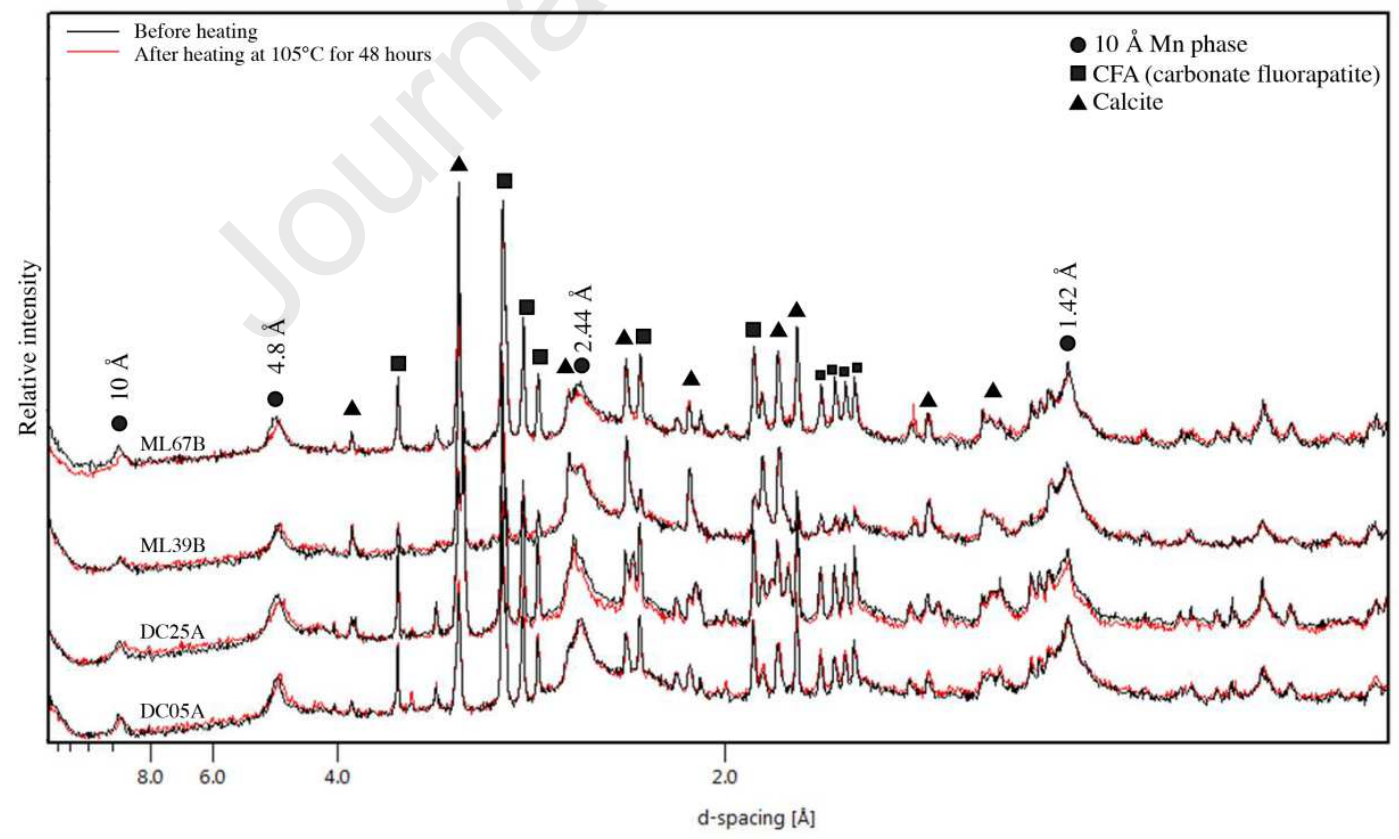

Fig. 8: XRD patterns of phosphatized crust samples. The $10 \AA$ peak remains present in all samples after heating at $105^{\circ} \mathrm{C}$ for 48 hours. 

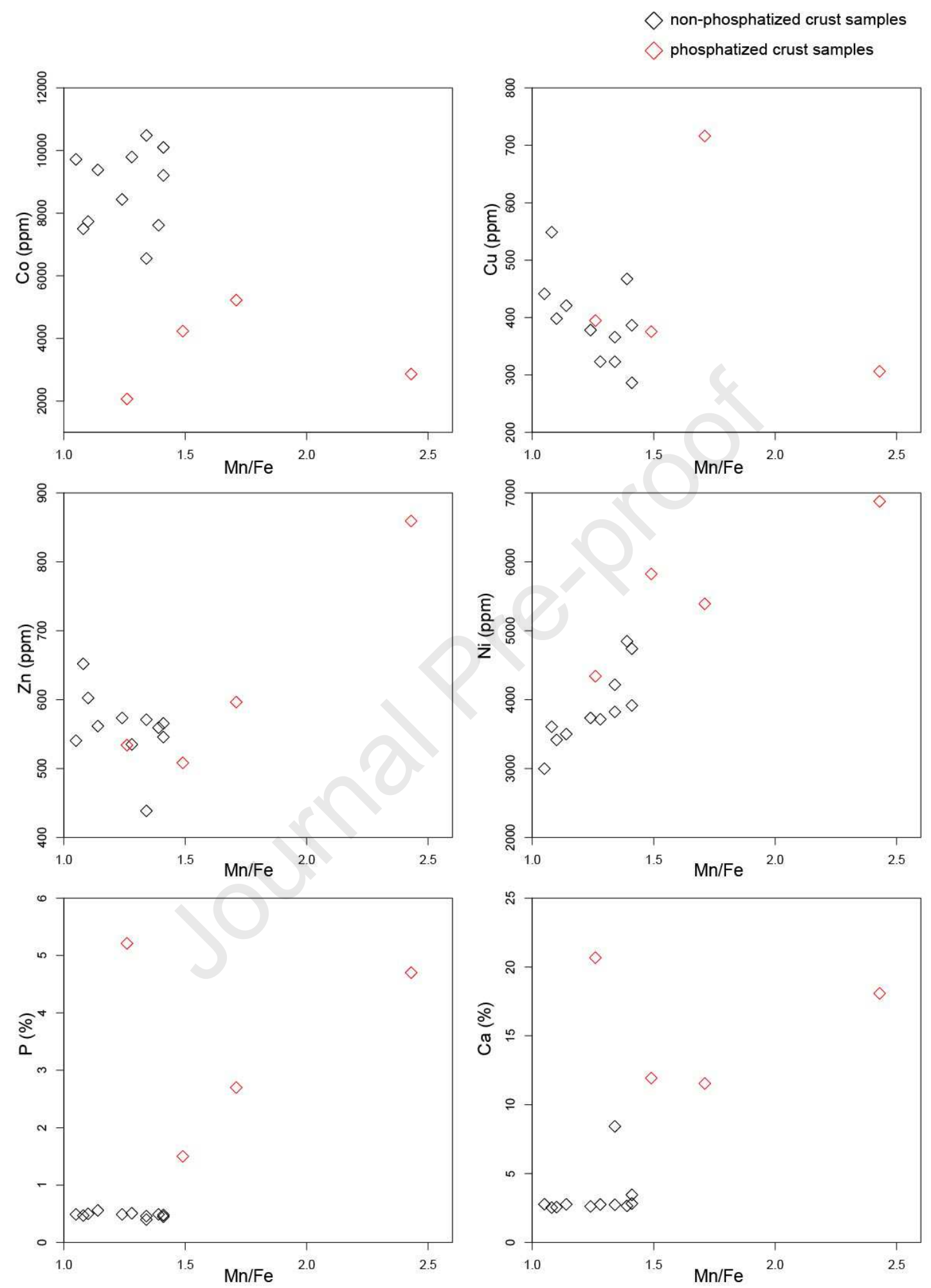

708 Fig. 9: $\mathrm{Mn} / \mathrm{Fe}$ vs elements of crusts from the escarpments of the Rio Grande Rise. Phosphatized crust samples present higher contents of $\mathrm{P}$ and $\mathrm{Ca}$. 


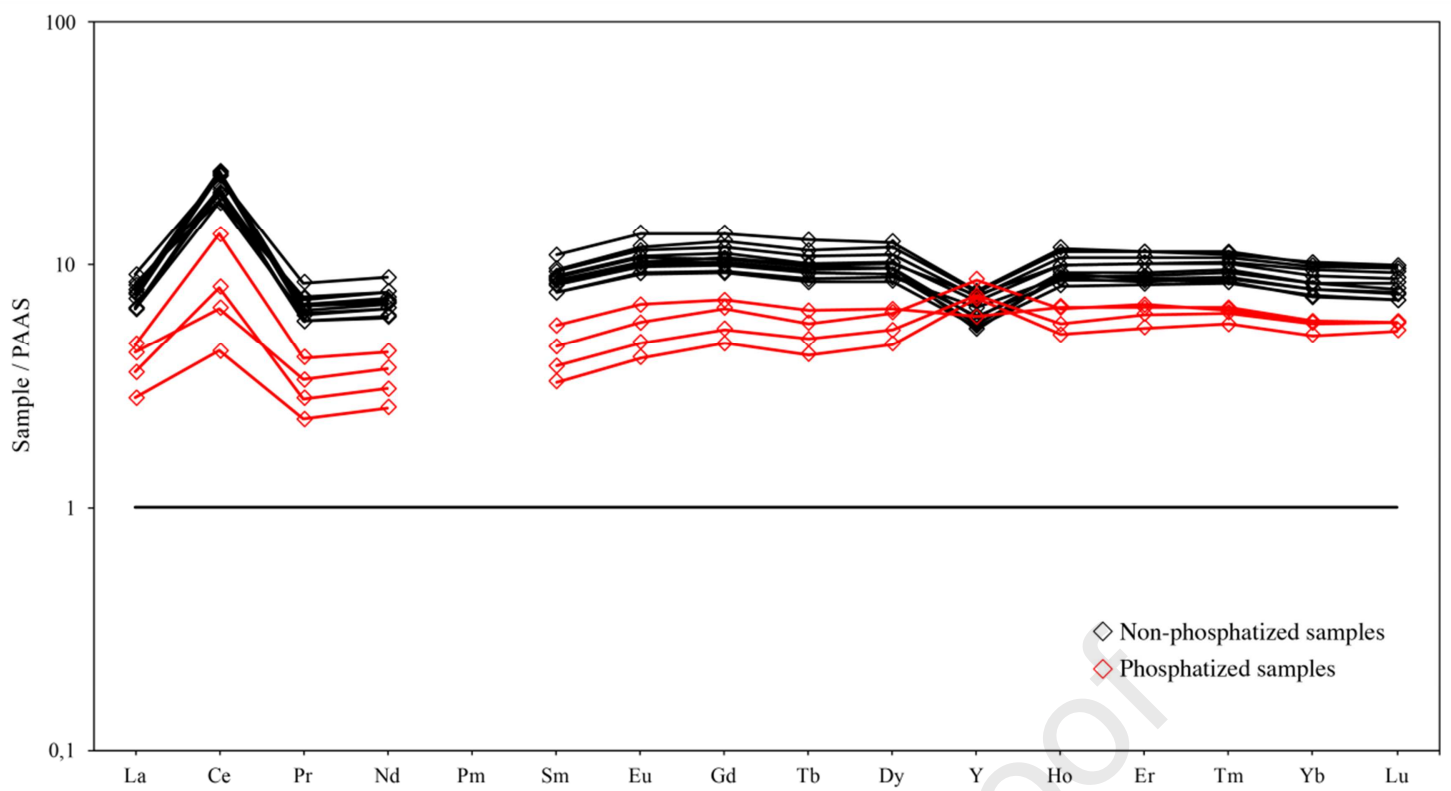

711 Fig. 10: REY pattern normalized to Post-Archean Australian Shale (PAAS, of McLennan, 1989) of Fe-

712 Mn crusts from the escarpments of the Rio Grande Rise.

713

A

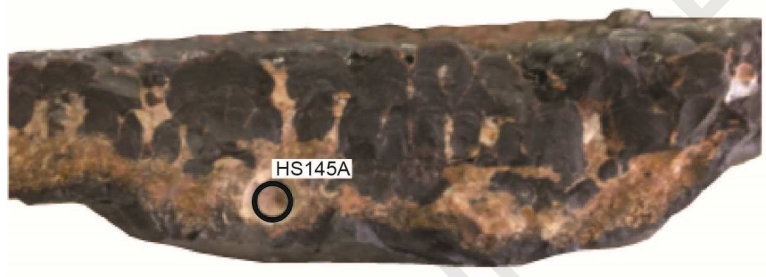

$2 \mathrm{~cm}$
B

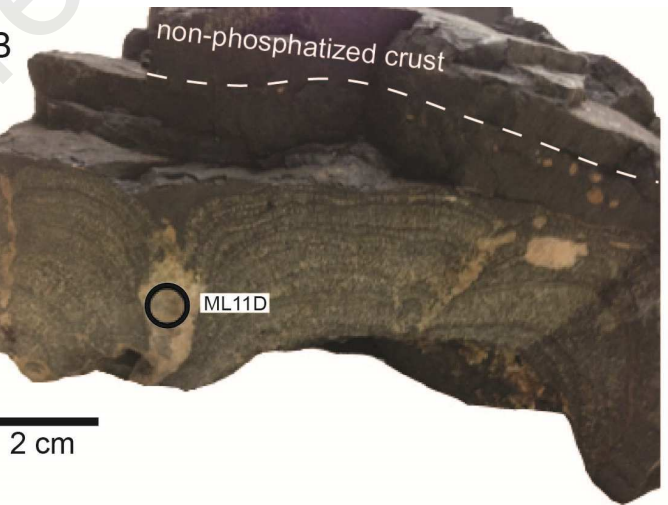

714

715 Fig. 11: Sample HS145A (A) and sample MLD11 (B) indicating where ${ }^{87} \mathrm{Sr} /{ }^{86} \mathrm{Sr}$ analyses were 716 performed.

717 


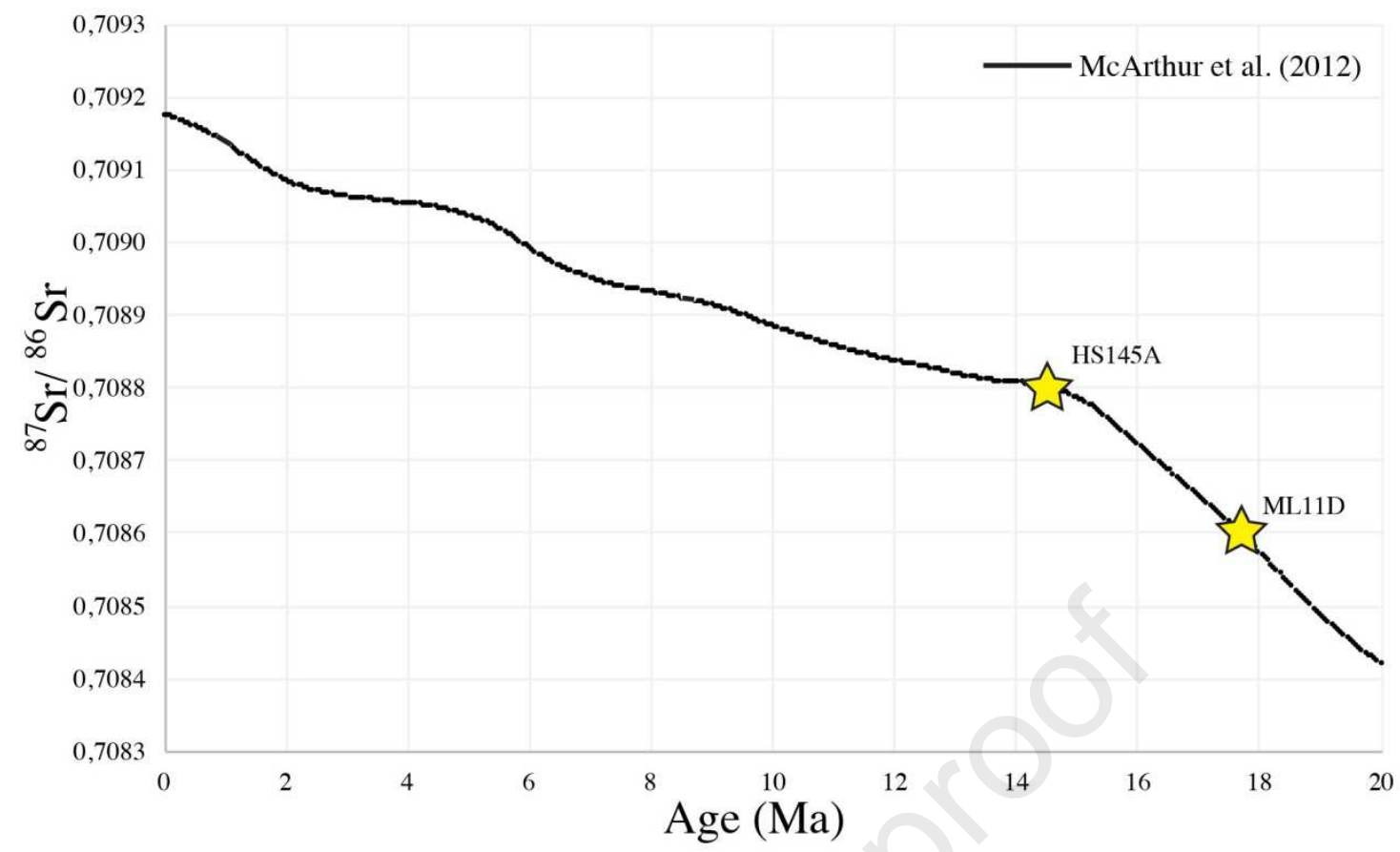

Fig. 12: Samples HS145a and ML11D plotted in ${ }^{87} \mathrm{Sr} /{ }^{86} \mathrm{Sr}$ curve from McArthur et al. (2012) for indirect dating.

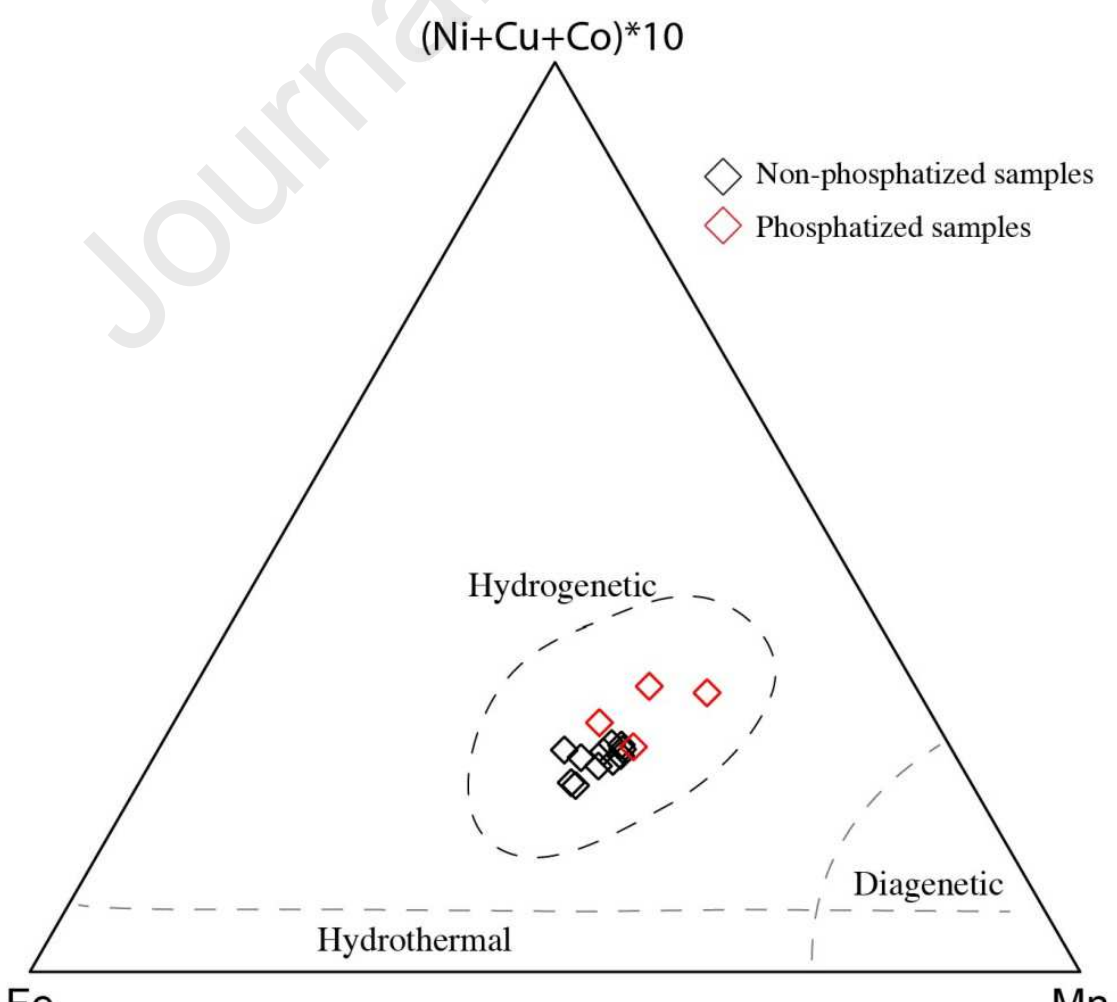

Fig. 13: Ternary diagram of $\mathrm{Mn}, \mathrm{Fe}$ and $(\mathrm{Ni}+\mathrm{Cu}+\mathrm{Co}) * 10$ modified from Bonatti et al. (1972). All analyzed samples plot in the hydrogenetic field. 

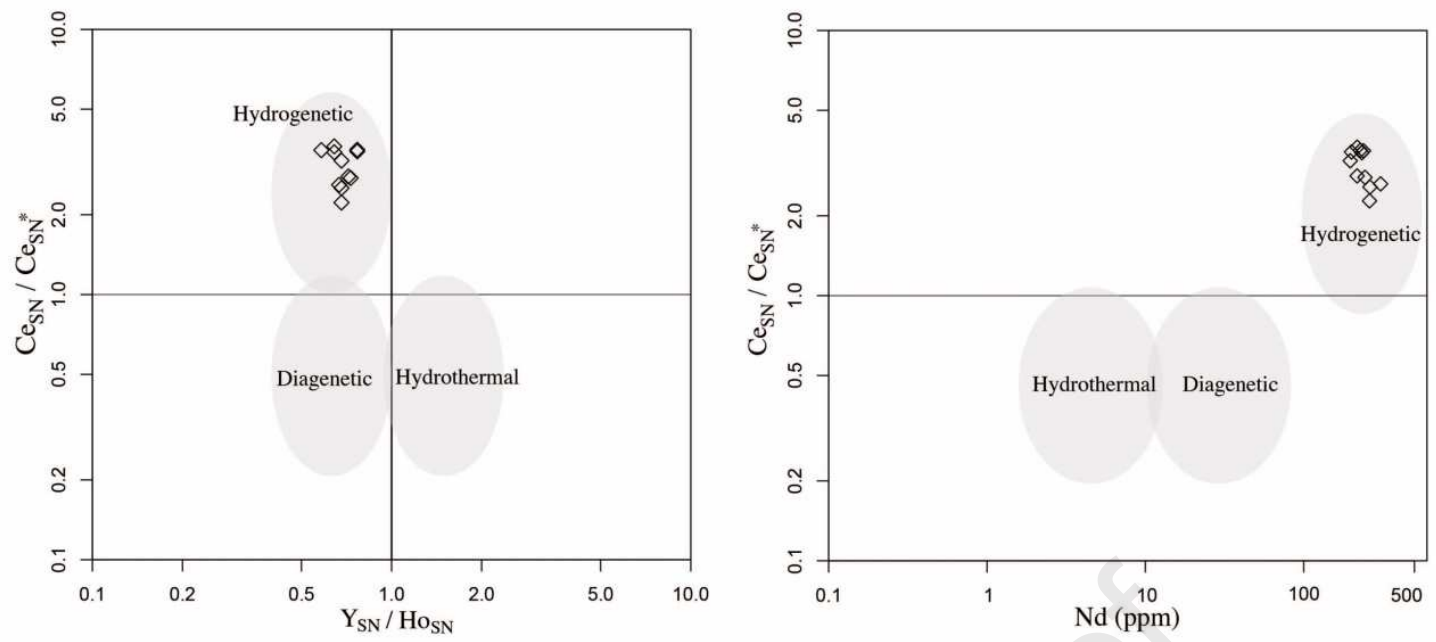

Fig. 14: $\mathrm{Y}_{\mathrm{SN}} / \mathrm{Ho}_{\mathrm{SN}}$ ratio vs $\mathrm{Ce}_{\mathrm{SN}} / \mathrm{Ce}_{\mathrm{SN}} *$, and $\mathrm{Nd}(\mathrm{ppm})$ vs $\mathrm{Ce}_{\mathrm{SN}} / \mathrm{Ce}_{\mathrm{SN}}{ }^{*}$. SN: shale normalized (PAAS) and $\mathrm{Ce}_{\mathrm{SN}}{ }^{*}=0.5 \mathrm{La}_{\mathrm{SN}}+0.5 \mathrm{Pr}_{\mathrm{SN}}$. The position of the samples indicated by diamond symbols is in the field of hydrogenetic Fe-Mn precipitates. Discriminant diagrams proposed by Bau et al. (2014). Phosphatized samples are not shown because the plot is not appropriate for phosphatized samples.

730

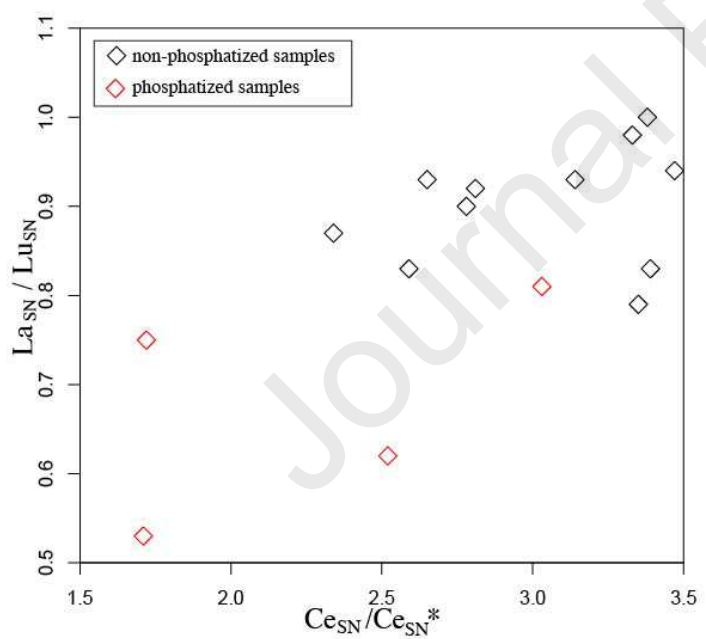

Fig. 15: $\mathrm{Ce}_{\mathrm{SN}_{\mathrm{N}}} / \mathrm{Ce}_{\mathrm{SN}_{\mathrm{N}}} *$ vs $\mathrm{La}_{\mathrm{SN}} / \mathrm{Lu}_{\mathrm{SN}}$. Phosphatized samples exhibit lower $\mathrm{La}_{\mathrm{SN}} / \mathrm{Lu}_{\mathrm{SN}}$ ratios for having carbonate fluorapatite, that is more enriched in HREE relative to LREE than oxy-hydroxides. $\mathrm{Ce}_{\mathrm{SN}} / \mathrm{Ce}_{\mathrm{SN}^{*}}$ * 


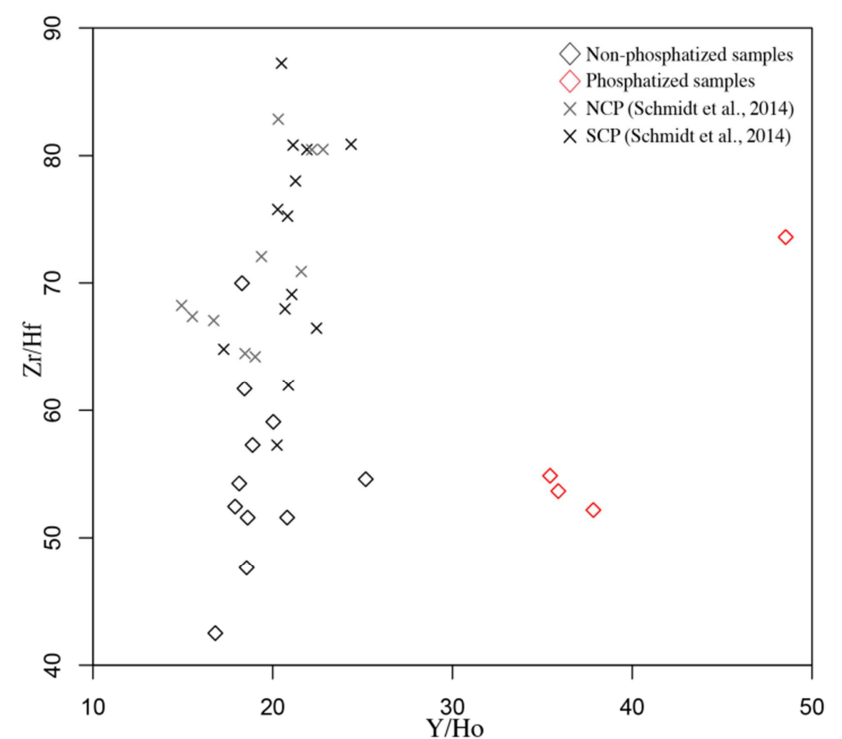

738 Fig. 16: Y/Ho vs $\mathrm{Zr} / \mathrm{Hf}$ plot of samples from the Pacific Ocean (Schmidt et al. 2014) and this study. $\mathrm{Zr} / \mathrm{Hf}$ ratios are higher in Pacific crusts because they formed in older and more scavenged waters, from which Hf has been removed by particle sorption. 
Mineralogy and chemical composition of ferromanganese crusts from the Cruzeiro do Sul Lineament - Rio Grande Rise, South Atlantic

Sousa, I.M.C., Santos, R.V., Koschinsky, A., Bau, M., Wegorzewski, A.V., Cavalcanti, J.A.D., Dantas, E.L.

\section{Highlights:}

- Non-phosphatized Fe-Mn crusts in the region developed above Miocene phosphorites.

- Phosphatization was probably caused by a Middle Miocene OMZ expansion in depth.

- Fe-vernadite is the mineral constituent of non-phosphatized Fe-Mn crusts.

- A stable $10 \AA-M n$ phase is the mineral constituent of phosphatized crusts.

- Estimated age of the crusts is in agreement with data from NE Atlantic. 


\section{Declaration of interests}

$\bigotimes$ The authors declare that they have no known competing financial interests or personal relationships that could have appeared to influence the work reported in this paper.

$\square$ The authors declare the following financial interests/personal relationships which may be considered as potential competing interests: 